\title{
Long-term Potentiation and Long-term Depression of Primary Afferent Neurotransmission in the Rat Spinal Cord
}

\author{
M. Randić, M. C. Jiang, and R. Cerne \\ Department of Veterinary Physiology and Pharmacology, lowa State University, Ames, lowa 50011
}

Synaptic transmission between dorsal root afferents and neurons in the superficial laminae of the spinal dorsal horn (laminae I-III) was examined by intracellular recording in a transverse slice preparation of rat spinal cord. Brief highfrequency electrical stimulation $(300$ pulses at $100 \mathrm{~Hz}$ ) of primary afferent fibers produced a long-term potentiation (LTP) or a long-term depression (LTD) of fast (monosynaptic and polysynaptic) EPSPs in a high proportion of dorsal horn neurons. Both the AMPA and the NMDA receptor-mediated components of synaptic transmission at the primary afferent synapses with neurons in the dorsal horn can exhibit LTP and LTD of the synaptic responses. In normal and neonatally capsaicin-treated rats, the induction of LTP requires the activation of NMDA receptor-gated conductances. The induction of LTP or LTD, however, was not abolished in the pres-

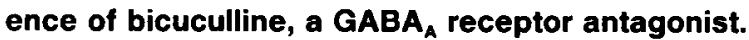

The results demonstrate that distinct and long-lasting modulation in synaptic efficiency can be induced at primary afferent synapses with neurons in the superficial laminae of spinal dorsal horn by high-frequency stimulation of dorsal root afferents and that these changes may be physiologically relevant for transmission and integration of sensory information, including pain.

IKey words: spinal dorsal horn neuron, synaptic plasticity, spinal dorsal horn, long-term potentiation, long-term depression, EPSPs]

The superficial spinal dorsal horn (SDH), including substantia gelatinosa (SG), is an area where primary afferent fibers arising predominantly from skin, but also the viscera and muscles, terminate and form the first synaptic relay with dendrites of dorsal horn (DH) ncurons. For this reason, the SDH has been regarded as an important site for the initial processing of afferent signals directly related to the transmission and modulation of cutaneous information, including pain.

Previous studies using spinal cord slice preparations from immature (Urbán and Randić, 1984; Gerber and Randić, 1989; Gerber et al., 1991) and adult (Yoshimura and Jessell, 1989, 1990) rats had demonstrated that primary afferent stimulation evokes both fast and slow EPSPs in SDH neurons, including SG. Pharmacologic evidence has indicated that fast EPSPs at synapses between $\mathrm{A} \delta$ and $\mathrm{C}$ afferents and $\mathrm{SG}$ neurons are prob-

Received Jan. 4, 1993; revised June 1, 1993; accepted June 10, 1993.

We thank Dr. T. Honore for kindly providing us with NBQX. This effort was supported by NIH Grant NS-26352, Grants BNS 8418042 and IBN-9209462 from the National Science Foundation, and the U.S. Department of Agriculture. Correspondence should be addressed to $M$. Randic at the above address.

Copyright (C) 1993 Society for Neuroscience $0270-6474 / 93 / 135228-14 \$ 05.00 / 0$ ably mediated by L-glutamate, or a related amino acid (Jahr and Jessell, 1985; Gerber and Randić, 1989; Kangrga and Randić, 1990, 1991; Yoshimura and Jessell, 1990; Cerne et al., 1991).

Neuronal excitatory amino acids (EAAs), including glutamate, produce their effects through two broad categories of receptors called ionotropic and metabotropic (Honoré et al., 1988; Schoepp et al., 1991; Watkins et al., 1990). The ionotropic NMDA, $\alpha$-amino-3-hydroxy-5-methyl-4-isoxazolepropionic acid (AMPA)/quisqualate (QA), and kainate receptors directly regulate the opening of ion channels to $\mathrm{Na}, \mathrm{K}^{+}$, and, in the case of NMDA receptors, $\mathrm{Ca}^{2+}$ as well (Mayer and Westbrook, 1987; Ascher and Nowak, 1987). In addition, the activation of ionotropic receptors can induce $\mathrm{Ca}^{2+}$ influx through voltage-dependent $\mathrm{Ca}^{2+}$ channels activated as a result of cell depolarization. The metabotropic receptors (activated by glutamate/QA) appear to be coupled to phospholipase $C$ through $\mathrm{G}$-proteins. Their activation causes an increase in turnover of polyphosphoinositides and release of $\mathrm{Ca}^{2+}$ from intracellular stores. Thus, the activation of both classes of EAA receptors can result in elevation of intracellular free $\mathrm{Ca}^{2+}$ concentration $\left(\left[\mathrm{Ca}^{2+}\right]_{i}\right)$ (Mayer and Miller, 1991). The increase in $\left[\mathrm{Ca}^{2+}\right]_{i}$, in turn, may lead to activation of other second messenger systems with consequent changes in the properties of EAA receptor channel complexes that contribute to long-term influences on the fast excitatory synaptic transmission (Collingridge and Singer, 1990; Madison et al., 1991; Siegelbaum and Kandel, 1991; Johnston et al., 1992).

The efficiency of synaptic transmission in the CNS, including spinal cord, is not constant and can be modulated by the rate of activity in presynaptic pathways (Mendell, 1984; Burke, 1987). In a variety of brain structures, repetitive activation of synaptic connections can lead to long-term potentiation (LTP) or longterm depression (LTD) of synaptic transmission (Ito, 1989; Collingridge and Singer, 1990; Madison et al., 1991; Siegelbaum and Kandel, 1991; Johnston et al., 1992). Although a great deal is known about LTP and LTD in the mammalian brain, the existence of similar synaptic plasticity at primary afferent synapses with DH neurons has not until recently been demonstrated (Cerne et al., 1991; Jiang and Randić, 1991).

The present work was aimed at studying long-term modifications of primary afferent neurotransmission following highfrequency stimulation of dorsal roots in spinal cord slices obtained from young rats. Our major findings were that in a high proportion of DH neurons (laminae I-III), a prolonged increase or decrease of amplitude of monosynaptic EPSPs can be induced by brief repetitive stimulation of primary afferent fibers in a dorsal root. In both normal and capsaicin-treated rats the induction of the potentiation requires the activation of NMDA 
receptor-gated conductances. The effect is, however, not abolished by blockade of $\mathrm{GABA}_{\mathrm{A}}$ receptors in polysynaptic pathways to primary afferents. Long-lasting depression of the primary afferent input to DH neurons, however, does not involve acti-

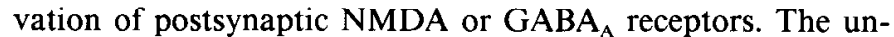
derlying molecular mechanisms responsible for positive or negative amplitude modulation of EPSPs in spinal DH neurons have yet to be identified.

Part of these results have been presented elsewhere (Cerne et al., 1991; Jiang and Randić, 1991; Randić et al., 1993; Rusin et al., 1993b).

\section{Materials and Methods}

Preparation of the spinal cord slice. Transverse slices were obtained from Sprague-Dawley rats of both sexes (14-40 d old) using a technique that has been described elsewhere (Murase and Randić, 1983, 1984; Gerber et al., 1989, 1991). Briefly, after the animal was anesthetized with ether, a segment of the lumbosacral $\left(\mathrm{L}_{4}-\mathrm{S}_{1}\right)$ spinal cord was dissected out and sectioned with a Vibratome to yield several transverse slices 300-400 $\mu \mathrm{m}$ thick with short $(3-6 \mathrm{~mm})$ dorsal rootlets (DRs) (Fig. 1A). After incubation for $1 \mathrm{hr}$ in a solution equilibrated with $95 \% \mathrm{O}_{2}, 5 \% \mathrm{CO}_{2}$ (mM: $\mathrm{NaCl}, 124 ; \mathrm{KCl}, 5 ; \mathrm{KH}_{2} \mathrm{PO}_{4}, 1.2 ; \mathrm{CaCl}_{2}, 2.4 ; \mathrm{MgSO}_{4}, 1.3 ; \mathrm{Na}-$ $\mathrm{HCO}_{3}, 26$; glucose, $10 ; \mathrm{pH} 7.4$, at $36 \pm 1{ }^{\circ} \mathrm{C}$ ), a slice was transferred into a recording chamber, where it was submerged beneath an oxygenated superfusing medium (flow rate of about $3 \mathrm{ml} / \mathrm{min}$ ) containing a lowered concentration of potassium ions $(1.9 \mathrm{~mm} \mathrm{KCl})$. The use of a high- $\mathrm{K}^{+}$solution during cutting and incubation of the slices seemed to improve their viability as assessed electrophysiologically in the same preparation.

Dorsal root stimulation and intracellular recording of synaptic responses. Conventional electrophysiological techniques were used for intracellular recording from DH neurons (laminae I-III), including SG cells, as described (Murase and Randić, 1983, 1984; Gerber et al., 1989, 1991). SG neurons were identified by their location in the spinal DH. When viewed under a dissecting microscope with transmitted illumination, the SG was distinguishable as a translucent bend in the superficial $\mathrm{DH}$, although it was difficult to discern with certainty the border between laminae I and II. Under visual control, a single fiber-glass (\#6010; o.d. and i.d., 1.0 and $0.58 \mathrm{~mm}$, respectively; AM Systems, Everett, WA) microelectrode filled with either $4 \mathrm{~m}$ potassium acetate or $4 \mathrm{M}$ potassium chloride ( $\mathrm{pH}$ 7.2) (DC impedance, 105-150 M $\Omega$ ) was placed in the DH (Fig. $1 A$ ), and neurons were impaled by oscillating the capacity compensation circuit of a high-input impedance bridge amplifier (Axoclamp 2). Cells were activated synaptically by electrical stimulation of primary afferent fibers in the dorsal roots. A coaxial stainless steel stimulating electrode (o.d. of inner and outer electrodes, 25 and $200 \mu \mathrm{m}$, respectively; Frederick Haer Co.) positioned on a lumbar DR was used in transverse slices (Fig. 1A). A DC pen-recorder was used to record membrane potential continuously; the synaptic responses were stored on diskettes of a digital oscilloscope.

Experimental arrangement. The protocol for assessing the effects of tetanic stimulation of primary afferents on excitatory synaptic responses was as follows. Once the electrode position was optimized on a DR, sampling of excitatory postsynaptic potentials (referred to as "test" EPSPs) began. Single shocks at a fixed suprathreshold strength $(0.05$ $0.2 \mathrm{msec}$ pulses, $5-30 \mathrm{~V}$ ), repeated at $30 \mathrm{sec}$ or $3 \mathrm{~min}$ intervals, were given through a stimulating electrode for 10-20 min before tetanic stimulation. This frequency of stimulation was chosen for sampling data because it did not result in response facilitation or depression. A stimulus intensity that yielded a 5-15 mV EPSP was chosen to standardize the baseline synaptic strength across slices, and it was below threshold for eliciting an action potential in most of the slices chosen for study. However, in some neurons, in order to obtain EPSPs of 5-15 mV amplitude without evoking action potentials in the postsynaptic cell, hyperpolarizing DC current (up to $0.1 \mathrm{nA}$ ) was passed into the cell for the duration of the experiment, resulting in measured resting membrane potentials of -70 to $-85 \mathrm{mV}$. After the baseline period of $10-20 \mathrm{~min}$, a high-frequency train (three tetani of $1 \mathrm{sec}$ duration, each at $100 \mathrm{~Hz}$ and $10 \mathrm{sec}$ intervals) was delivered at the test or greater intensity $(0.05$ $0.2 \mathrm{msec}$ pulses, $20-35 \mathrm{~V}$ ), as used for the baseline responses. Normally the first tetanization utilized stimulus pulses of the same intensity and duration as during test stimulation. If this treatment did not induce
A

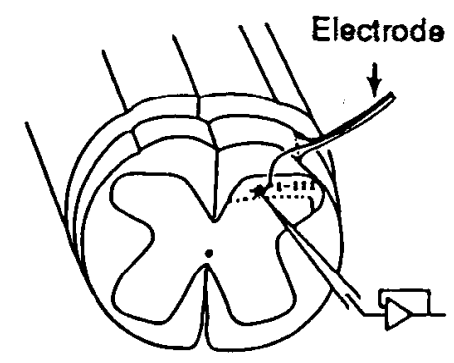

B
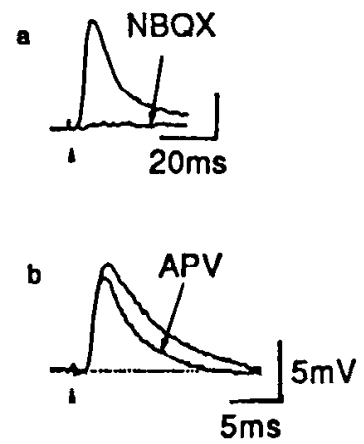

Figure 1. Schematic arrangement for intracellular recording and dorsal root stimulation. $A$, Dorsal root was stimulated by a coaxial stainless steel stimulating electrode (arrow). $B$, Presumed monosynaptic EPSPs evoked by single electrical shocks ( $a$ and $b$ ) are shown before and during bath application of $5 \mu \mathrm{M} \operatorname{NBQX}(a)$ and $100 \mu \mathrm{M}$ APV $(b)$.

change in size of EPSPs, and the synaptic responses remained stable, then subsequent tetani utilized pulses of increased intensity. The test stimuli were always the same before and after tetani.

Data analysis. The chief dependent variable in the intracellular studies was the EPSP amplitude. LTP or LTD magnitude was quantified from the peak amplitude of a single or averaged $\operatorname{EPSP}(n=4)$ measured at the time of maximal change $(21.8 \pm 1.8 \mathrm{~min}$, mean $\pm \mathrm{SEM}, n=53)$ posttetanus with respect to the pretetanus baseline EPSP. LTP was defined as at least a $20 \%$ increase in amplitude of the synaptic response that was maintained for a minimum of 20 min following brief highfrequency stimulation. Conversely, LTD was defined as at least a $20 \%$ decrease in amplitude of EPSP lasting at least $20 \mathrm{~min}$. Statistical significance of data has been assessed relative to control responses by use of either a paired or unpaired Student's $t$ test, as appropriate. For statistical analysis of data seen in Figure 4 we used one-way ANOVA, and statistical significance between means was determined by a StudentNewman-Keuls test. All values are expressed as means \pm SEM. The significance level for all statistical tests was $P \leq 0.05$.

Application of drugs. Drugs were applied by superfusing slices with solutions of known drug concentration. Drugs uscd werc 2,3-dihydroxy6-nitro-7-sulfamoyl-benzo(F)quinoxaline (NBQX; 0.5-20 $\mu \mathrm{M}$; a gift from Dr. T. Honoré, A/S Ferrosan, Soeborg, Denmark), 6-cyano-7-nitroquinoxaline-2,3-dione (CNQX; 5-10 $\mu \mathrm{M}$; Tocris), D-2-amino-5-phosphonovaleric acid (APV; 50-100 $\mu \mathrm{M}$; Cambridge Research Biochemicals), bicuculline methiodide (5-10 $\mu \mathrm{M}$; Sigma), L-glutamate (Peptides International, Sigma), and $N$-methyl-D-aspartic acid (NMDA; CRB).

Capsaicin experiments. Sixteen rats of both sexes taken from two different litters were injected subcutaneously with $50 \mathrm{mg} / \mathrm{kg}$ capsaicin (Sigma) in vehicle [ $10 \%$ ethanol, 10\% Tween $(\mathrm{v} / \mathrm{v})$ in $0.9 \%(\mathrm{w} / \mathrm{v})$ saline] $48 \mathrm{hr}$ after birth. Ten control littermates received equal volumes of vehicle alone. After a survival time of 14-29 d, the animals were subjected to the experimental procedure described above.

\section{Results}

Stable intracellular recordings of up to $5 \mathrm{hr}$ were obtained from $92 \mathrm{DH}$ neurons, including $81 \mathrm{SG}$ cells, that received fast EPSPs elicited by stimulation of primary afferent fibers in the DR. The resting membrane potential and action potential amplitude of DH neurons examined were $-73.0 \pm 0.8 \mathrm{mV}$ (mean $\pm \mathrm{SEM}$, $n=83$ ) and $78.5 \pm 1.8 \mathrm{mV}$, respectively.

\section{EPSPs evoked by primary afferent stimulation and their antagonism by $N B Q X$ and $A P V$}

Primary afferent stimulation produces several distinct types of EPSPs in superficial laminae of the SDH, including SG neurons, as has been reported previously (Yoshimura and Jessell, 1990). In 69 of $92(75 \%)$ DII neurons, the poststimulus latency of DR- 
Table 1. The effects of repetitive stimulation of primary afferent fibers on EPSPs in SG neurons

\begin{tabular}{lllcll} 
Type of EPSP & $\begin{array}{l}\text { Type of } \\
\text { change } \\
\text { in EPSP }\end{array}$ & $n$ & $\begin{array}{l}\text { Maximal change } \\
\text { (\% control) }\end{array}$ & $\begin{array}{l}\text { Peak change } \\
\text { (min) }\end{array}$ & $\begin{array}{l}\text { Resting } \\
\text { potential } \\
\text { (mV) }\end{array}$ \\
\hline Monosynaptic & LTP & 22 & $173.6 \pm 10.8$ & $20.0 \pm 3.7$ & $70.5 \pm 1.4$ \\
EPSP & LTD & 20 & $44.5 \pm 4.7$ & $21.4 \pm 1.6$ & $74.3 \pm 1.5$ \\
Poly-synaptic EPSP & LTP & 17 & $177.1 \pm 17.3$ & $18.9 \pm 2.1$ & $73.4 \pm 1.7$ \\
& LTD & 6 & $42.5 \pm 9.8$ & $23.5 \pm 3.3$ & $74.2 \pm 3.2$ \\
EPSP in capsaicin- & LTP & 6 & $182.8 \pm 12.0$ & $16.8 \pm 2.7$ & $70.7 \pm 7.8$ \\
treated rats & LTD & 7 & $39.2 \pm 4.9$ & $18.6 \pm 1.6$ & $70.6 \pm 4.4$ \\
NMDA component & LTP & 4 & $237.0 \pm 89.3$ & $12.8 \pm 5.2$ & $59.0 \pm 1.9$ \\
of EPSP & LTD & 5 & $43.1 \pm 13.4$ & $14.2 \pm 3.3$ & $70.2 \pm 3.4$ \\
\hline
\end{tabular}

Changes in the amplitude of synaptic responses produced by electrical stimulation of DRs are presented as mean percentages of their respective controls \pm SEM.

initiated EPSPs remained constant when repetitive stimulation $(10 \mathrm{~Hz})$ was used and failures were not observed, although the amplitude of EPSPs was significantly decreased during stimulation. The latency of these EPSPs also remained constant in the presence of a high concentration of divalent cations ( $4 \mathrm{mM}$ $\mathrm{Ca}^{2+}, 8 \mathrm{mM} \mathrm{Mg}^{2+}$; data not shown). On the basis of these criteria we assumed that these $\mathrm{DH}$ neurons are monosynaptically activated by primary afferent fibers. In a smaller proportion of DH neurons $(25 \%, n=23)$, the latency of the DR-evoked EPSPs was variable, suggesting a polysynaptic input from primary afferents. Increasing the intensity of primary afferent stimulation usually increased the amplitude and duration of the polysynaptic EPSPs, whereas perfusion with Krebs solution containing $4 \mathrm{~mm}$ $\mathrm{Ca}^{2+}, 8 \mathrm{mM} \mathrm{Mg}{ }^{2+}$ markedly depressed variable latency EPSPs.

To test further the possibility that L-glutamate or a related amino acid is the transmitter at primary afferent synapses, we examined the sensitivity of monosynaptic EPSPs to EAA receptor antagonists. Bath-applied NBQX (1-20 $\mu \mathrm{M}$ for 2-13 $\mathrm{min}$ ), the novel and selective non-NMDA receptor antagonist (Sheardown et al., 1990), caused potent and reversible antagonism of EPSPs. The amplitude of EPSPs was significantly reduced (to $3.0 \pm 0.8 \%, n=26$ ) with $1 \mu \mathrm{M} \mathrm{NBQX}$, and the EPSPs were completely blocked with 5-10 $\mu \mathrm{M} \operatorname{NBQX}(n=6$; Fig. $1 B a)$.

APV (50-100 $\mu \mathrm{M}, 7-14 \mathrm{~min}$ ), the selective NMDA receptor antagonist (Davies et al., 1981; Watkins and Evans, 1981), produced a small decrease (to $75.3 \pm 7.3 \%$ of control, $n=10$; Fig. $1 \mathrm{Bb}$ ) in the amplitude of most EPSPs, although in two cells with long-latency EPSPs almost complete block occurred. In addition, almost all cells showed a decrease in the half-decay time of the EPSP. Our results obtained with NBQX and APV indicate that the synaptic activation of the non-NMDA receptors of SDH neurons predominantly mediates the DR-evoked, presumably
Figure 2. LTP of fast excitatory synaptic transmission at primary afferent synapses with neurons in the superficial SDH. $A$, The graph shows the time course of LTP of EPSP recorded intracellularly from an SDH neuron (inset) in response to electrical stimulation (20 $\mathrm{V}, 0.1 \mathrm{msec}$ ) of a lumbar dorsal root. At time 0 (arrow) the dorsal root was given three tetani (at the same intensity as the test stimulus) of $1 \mathrm{sec}$ duration, each at $100 \mathrm{~Hz}$ and $10 \mathrm{sec}$ intervals. Above the graph are displayed individual, apparently monosynaptic EPSPs taken before (trace 1) and during (trace 2) the potentiation. $B$, Summarized data (mean \pm SEM) showing the time course of the long-lasting potentiation for this and two other neurons (inset) following the tetanic stimulation at the intensity of the test stimulus. $C$, Even longerlasting potentiation of dorsal root stimulation $(9 \mathrm{~V}, 0.1 \mathrm{msec})$-evoked EPSPs, recorded from another SDH neuron (inset), was obtained when the tetanic stimulation was twice the test intensity. $D$, Responses for this and five other neurons are summarized below. $A, V_{m}$ $=-70 \mathrm{mV}, 33$-d-old rat; $B, V_{m}--72$ $\mathrm{mV}, 20$-d-old rat; $C, V_{m}=-64$ to -74 $\mathrm{mV}, 21-33$-d-old rats; $D, V_{m}=-65$ to $-84 \mathrm{mV}, 22-40$-d-old rats.

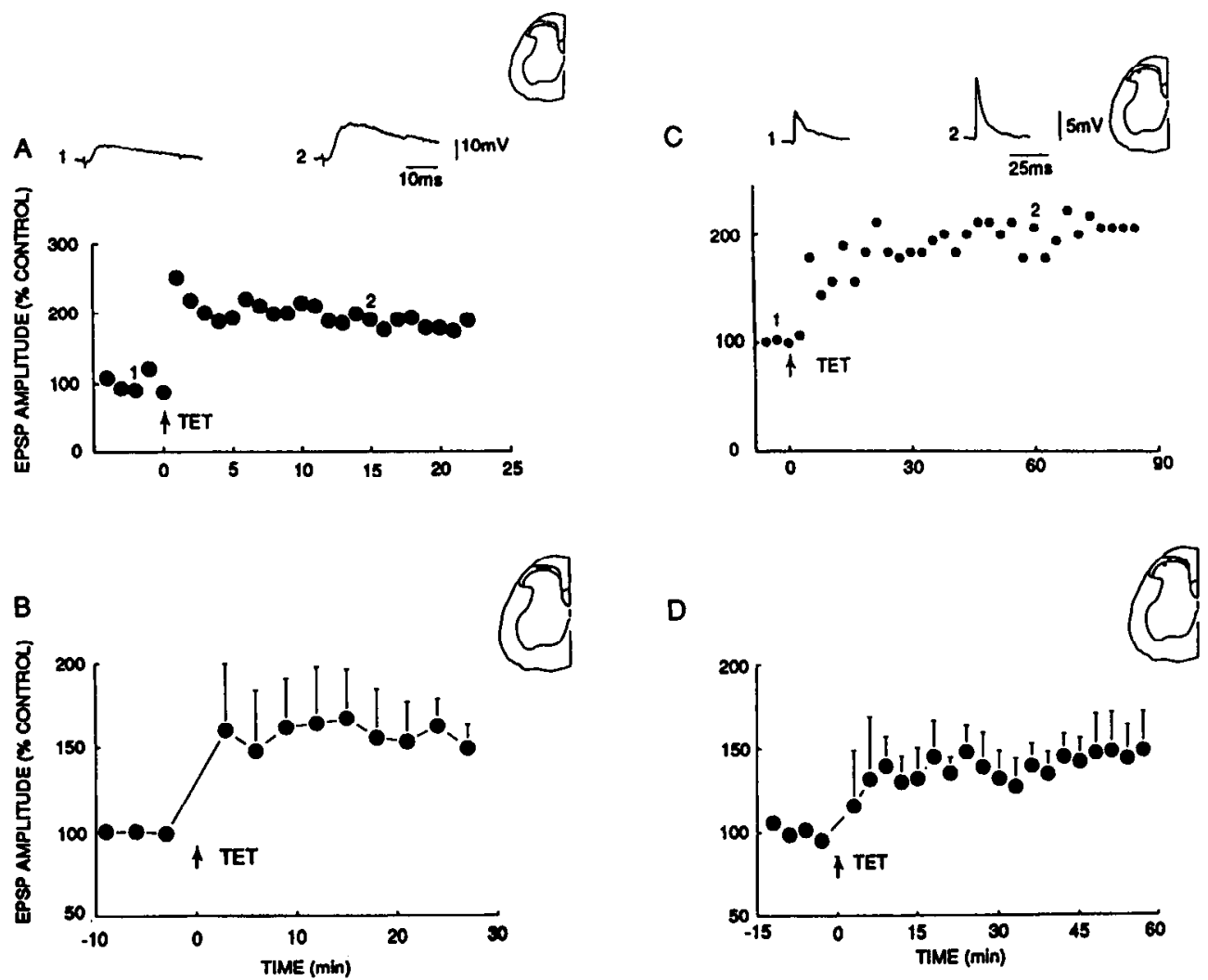



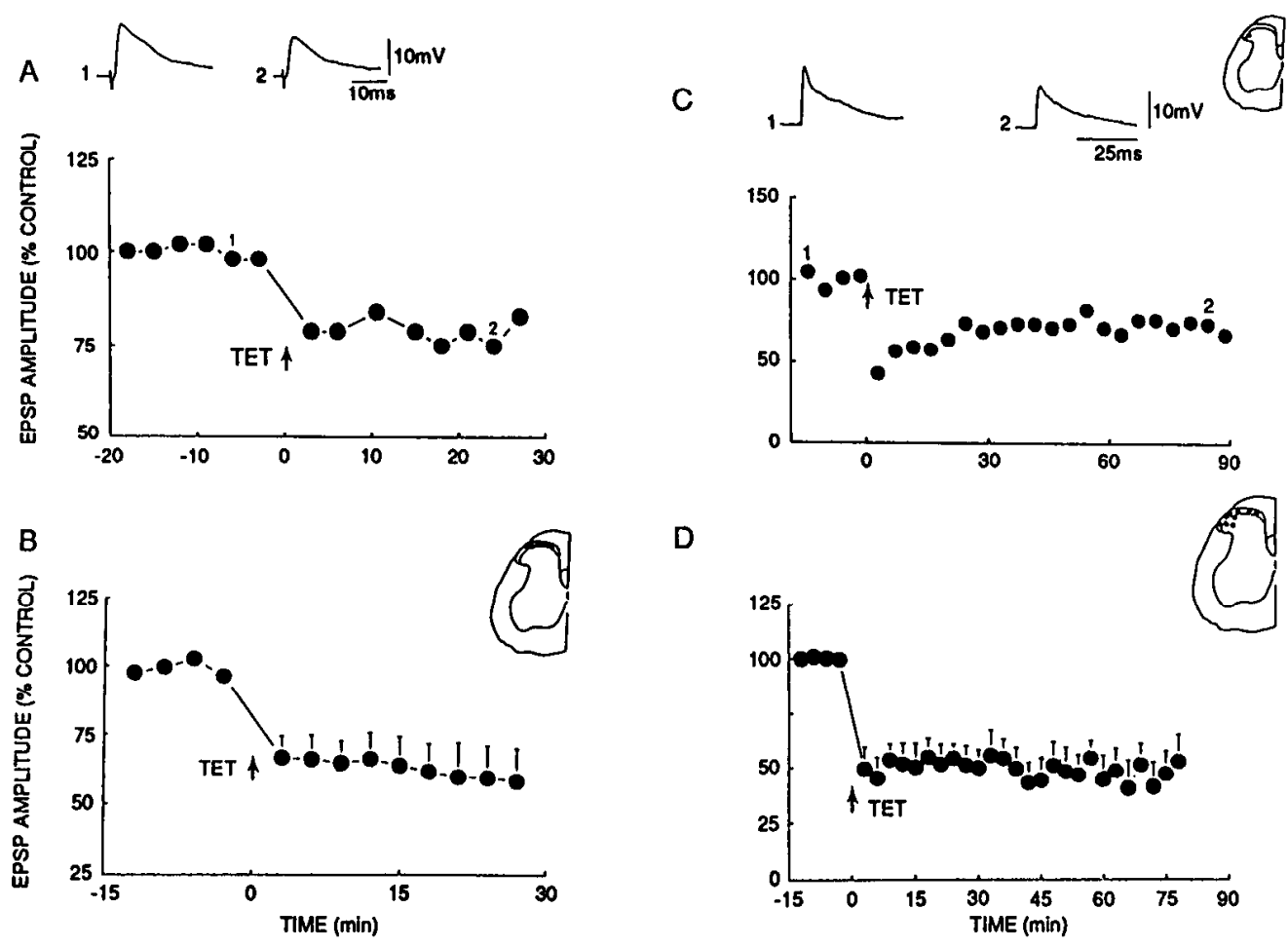

Figure 3. LTD of fast excitatory synaptic transmission in the superficial SDH. $A$, The graph shows the time course of LTD of an apparent monosynaptic EPSP recorded in an SDH neuron in response to stimulation ( $11 \mathrm{~V}, 0.1 \mathrm{msec}$ ) of a dorsal root. At time 0 (arrow), the dorsal root was given three tetani (test intensity) of $1 \mathrm{sec}$ duration, each at $100 \mathrm{~Hz}$ and $10 \mathrm{sec}$ intervals. Above the graph are displayed individual EPSPs taken before (trace 1) and during (trace 2) the LTD. B. The summarized data showing the time course for nine SDH neurons that expressed LTD when given the tetanic stimulation at the test stimulus intensity. Inset shows positions of the cells in SDH. $C$, The graph shows the time course of LTD of an apparent monosynaptic EPSP recorded in response to stimulation $(15 \mathrm{~V}, 0.3 \mathrm{msec}$ ) of a dorsal root. At time 0 (arrow), the dorsal root was given three tetani (35 V, $0.3 \mathrm{msec}$ ) of $1 \mathrm{sec}$ duration, each at $100 \mathrm{~Hz}$ and $10 \mathrm{sec}$ intervals. Posttetanic depression of the EPSP's amplitude to $40 \%$ of the control value was followed by long-lasting depression to $70 \%$ of the control EPSP's amplitude. $D$, The graph shows summarized results for nine SDH neurons that upon tetanic stimulation of high intensity (twice or three times the intensity of the test stimuli for a single EPSP) developed LTD. $A, V_{m}=-73 \mathrm{mV}, 22$-d-old rat; $B, V_{m}=-83 \mathrm{mV}, 20$-d-old rat; $C, V_{m}=-69$ to $-90 \mathrm{mV}, 19-25$-d-old rats; $D, V_{m}=-63$ to $-75 \mathrm{mV}, 18-$ 28-d-old rats.

monosynaptic, EPSP. These findings are consistent with other published reports for spinal neurons (Dale and Roberts, 1985; Forsythe and Westbrook, 1988; Schneider and Perl, 1988; Gerber and Randić, 1989; Yoshimura and Jessell, 1990; Cerne et al., 1991; Jiang and Randić, 1991; Yoshimura and Nishi, 1993).

\section{Changes in synaptic efficacy induced by tetanization of the primary afferents}

We have investigated in the present experiments the excitatory synapse between primary afferent fibers and neurons in the superficial laminae (I-III) of the SDH. The strength of primary afferent transmission was assayed by conventional intracellular recording of the size of the monosynaptic EPSPs that result from stimulation of primary afferent fibers with electrical shocks (Fig. $1 B$ ). With single stimuli delivered at a frequency of $0.002-0.033$ $\mathrm{Hz}$, the synaptic strength varies little over $1 \mathrm{hr}$ of testing. However, when high-frequency stimulation (typically these trains consisted of electrical shocks at the same or greater intensity as the test stimulus for single EPSP, delivered at $100 \mathrm{~Hz}$ for $1 \mathrm{sec}$, repeated three times at $10 \mathrm{sec}$ intervals) was applied to a dorsal root, two distinct types of changes in the monosynaptic EPSP amplitude resulted (Table 1). Of the 49 neurons having stable resting membrane potential and stable baseline EPSP size, 22 (45\%) showed a long-lerm enhancement of EPSP amplitude (Figs. 2, 4A; Table 1), 20 (41\%) showed a long-term decrease (Figs. 3, 4B; Table 1), and 7 (14\%) were not influenced.
It appears that the same tetanic stimulation can induce either LTP or LTD of the evoked EPSP depending on the level of membrane potential of the postsynaptic neuron $(n=5)$ and intensity of the conditioning train $(n=7)$. As illustrated in Figure 5 , when the membrane potential was regulated during synaptic use by directly passing a depolarizing or hyperpolarizing current through the recording electrode in the same DH cell kept at $-70 \mathrm{mV}$, tetanic stimulation induced LTP (Fig. 5A), whereas at $-85 \mathrm{mV}$ the same train led to LTD (Fig. $5 \mathrm{C}$ ). At the same membrane potential, the same tctani never resulted in alternate LTP or LTD. When tetanic stimulation given at test intensity for single EPSP evoked LTP, a subsequent train of higher strength also induced LTP. However, in the cells where LTD was evoked with the first train, a successive train, given at a higher intensity, produced either LTP or LTD. The latter result suggests that the sign of use-dependent synaptic modification in a proportion of DII neurons switches from negative to positive as a function of the activation level.

\section{LTP of the monosynaptic EPSPS}

Brief, high-frequency (tetanic) stimulation of primary afferent fibers resulted in the following sequence of results: (1) a rapid buildup of the slow depolarization during the tetanic stimulation, (2) a brief period of EPSP potentiation or depression immediately after the tetanic stimulation, and (3) a prolonged phase of EPSP potentiation involving both monosynaptic and poly- 
A

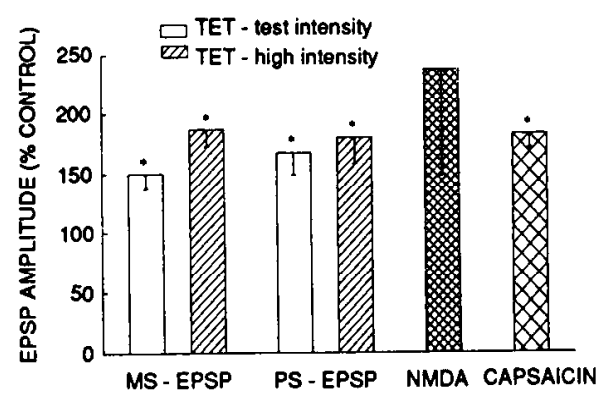

B

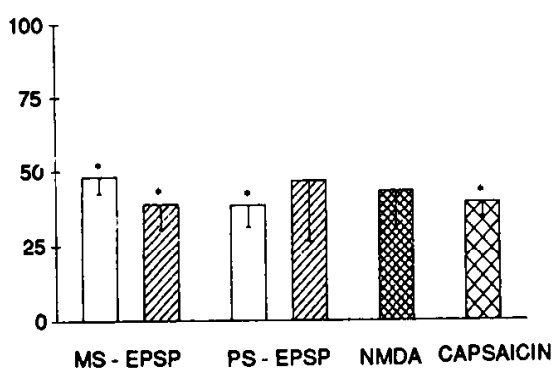

Figure 4. Summarized effects of tetanic stimulation of primary afferents on various forms of EPSPs in SDH neurons. Tetanic stimulation (100 $\mathrm{Hz}, 3 \times 1 \mathrm{sec})$ of primary afferents produced long-lasting modulation of EPSPs evoked by the low-frequency $(0.002-0.033 \mathrm{~Hz})$ dorsal root stimulation in a proportion of SDH neurons. The bar graphs show the maximal potentiation and depression of the amplitude of EPSPs, expressed as percentage change of control EPSP taken as the average of two to four EPSPs preceding the tetanus (mean \pm SEM; ${ }^{*}, P<0.05$ ). $A$, The potcntiation was maximal $20 \mathrm{~min}$ after the tetanus and was present in both monosynaptic $(M S-E P S P ; n=22)$ and polysynaptic $(P S-E P S P ; n=17)$ EPSPs. The effect was somewhat greater with tetani of higher stimulus intensity (diagonal hatched bar) than with tetani of the test stimulus intensity for single EPSP (open bar) and was observed also in the presence of $2-5 \mu \mathrm{M}$ NBQX $(N M D A ; n=4)$ and in neurons obtained from capsaicin-pretreated rats $(n=6) . B$, The long-lasting depression was maximal $21 \mathrm{~min}$ after the tetanic stimulation. There was no significant difference in the effects observed on monosynaptic $(M S-E P S P ; n=31)$ and polysynaptic $(P S-E P S P ; n=6)$ EPSPs and between tetani of the test or higher intensity. LTD was observed also in the presence of NBQX at 2-10 $\mu \mathrm{M}(N M D A ; n=5)$ and in capsaicin-pretreated rats $(n=7) . V_{m}=-56$ to $-90 \mathrm{mV}, 14-40$-d-old rats.

synaptic components of the evoked EPSP. This sequence was a characteristic feature of the experiments, although there was notable variation in the extent and duration of these three phases.

During each of the short trains of the tetanus, the $E_{M}$ depolarized up to $20 \mathrm{mV}$. Whereas in some cells EPSPs were evoked by every stimulus in the train, in others failures were observed. It was not possible, however, to perform precise measurements of their amplitude because of the distortion of records caused by the high-frequency stimulation. Tetanization was followed in many cases by a short-lasting (from 2 to $5 \mathrm{~min}$ ) increase in
Figure 5. The effects of prolonged depolarizing and hyperpolarizing DC current injections on induction of LTP $(A)$ and LTD $(C)$ of EPSPs. Tetanic stimulus was given at the test intensity (10 $\mathrm{V}, 0.1 \mathrm{msec}$ ). Time course of posttetanic changes of EPSP amplitude in the same SDH neuron (location shown in inset) conditioned with depolarizing ( $A$, $\left.V_{m}=-70 \mathrm{mV}\right)$ and hyperpolarizing $(B$, $V_{m}=-85 \mathrm{mV}$ ) currents is shown. Above the graphs are displayed individual EPSPs obtained before $(A, C$, trace 1$)$ and during LTP $(A$, trace 2$)$ or LTD ( $C$, trace 2$)$. $B$ and $D$, Summarized data showing the time course of the posttetanic changes of EPSPs in the same cells $(n=3$; inset) conditioned with depolarizing $(B)$ and hyperpolarizing $(D)$ pulses. $A$ and $C, 21$-d-old rat; $B$ and $D, 21-25$-d-old rats.
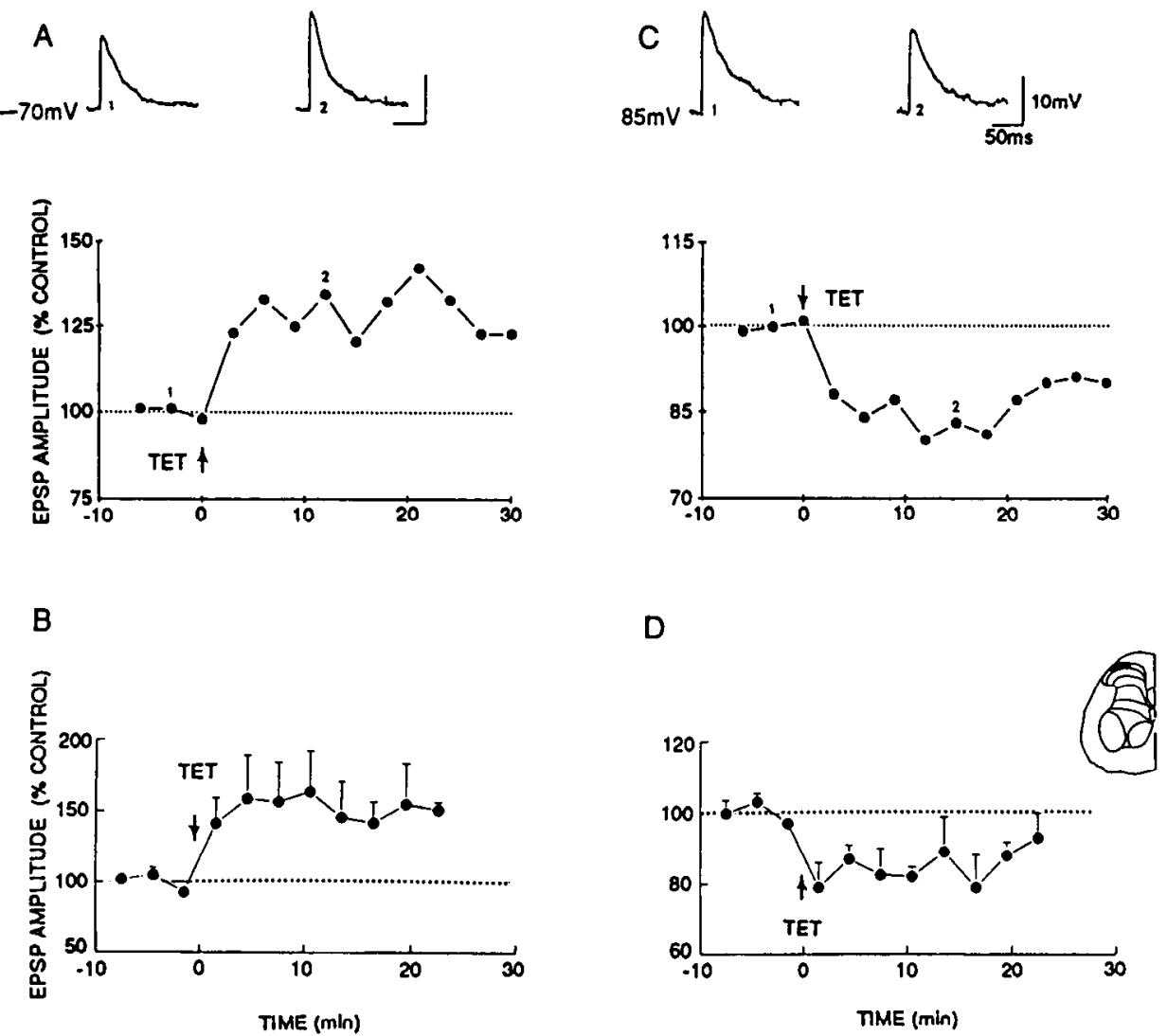

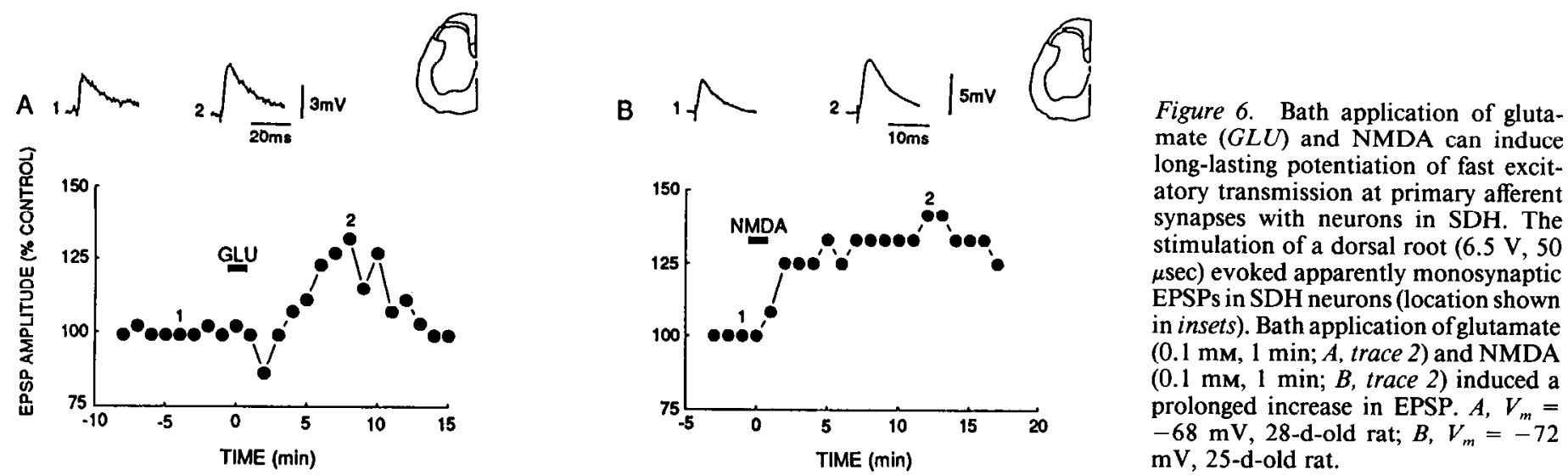

EPSP amplitude (posttetanic potentiation, or PTP), probably resulting from an increase in transmitter release from presynaptic terminals. LTP of the evoked EPSP, as manifested by an increase in slope and amplitude of EPSP, was induced in 7 of $49(14 \%)$ SDH cells when tetanic stimulation at the test intensity for single EPSP was employed. The LTP varied in magnitude, resulting in EPSPs that were between $120 \%$ (control being 100\%) and $210 \%$ of the amplitude of EPSPs during the control period (Figs. $2 B, 4 A$; Table 1). The potentiation always lasted for the duration of the recording period, which ranged from $25 \mathrm{~min}$ to $90 \mathrm{~min}$ (Fig. $2 A, C$ ). No change was detected in the evoked EPSP latency during LTP. The result of one of the experiments is shown in Figure $2 A$. Immediately following tetanic stimulus, the strength of the tetanized synaptic connections, as tested with single shock stimuli, increased (PTP) up to about 2.5-fold. Most of this increase decays to a level of about $200 \%$ of baseline within a few minutes after the tetanus. The graph in Figure $2 B$ shows the time course of the EPSP potentiation summarized for three cells.

In the next series of experiments we increased postsynaptic activation by raising the strength of tetanic stimulus two- to fourfold the test intensity for single EPSP and obtained LTP of the monosynaptic EPSP that lasted up to $90 \mathrm{~min}$ in 15 of 49 $(31 \%)$ cells tested (Fig. $2 C$ ). The potentiation of the EPSP can be seen not only as an increase in the peak amplitude but also as an increase in the initial slope of EPSP. Of 13 cells examined, 11 showed no change in EPSP latency, whereas in two cells a decrease was detected.

\section{Glutamate and NMDA potentiate synaptic transmission in $D H$ neurons}

The present concept is that the site of induction of LTP in the CAl region of hippocampus appears to be the postsynaptic cell, and induction requires both activation of NMDA receptors by synaptically released glutamate (Collingridge et al., 1983) and depolarization of the postsynaptic membrane (Gustafsson and Wigström, 1986). Moreover, it is thought that this depolarization relieves a voltage-dependent $\mathrm{Mg}^{2+}$ block of the NMDA receptor-ion channel complex, resulting in increased calcium influx (Mayer et al., 1984; Nowak et al., 1984), the latter being the trigger for the induction of LTP (Madison et al., 1991; Siegelbaum and Kandel, 1991). This model predicts that application of a large depolarizing dose of NMDA or glutamate should also evoke LTP. In order to determine the effects of glutamate and NMDA on primary afferent neurotransmission, we have examined the long-term effects of these agents applied to the bath on the DR-evoked EPSPs in DH (laminae I-III) neurons. We found that glutamate $\left(10^{-5}\right.$ to $10^{-4} \mathrm{M}$ for $\left.1 \mathrm{~min}\right)$ in five spinal slices produced a transient depression of the monosynaptic EPSP followed by a potentiation (Fig. 6A). The depression was usually associated with a reduction in the membrane potential. Furthermore, NMDA $\left(10^{-4} \mathrm{M}\right.$ for $\left.1 \mathrm{~min}\right)$ potentiated an apparent monosynaptic EPSP (Fig. 6B). Primary afferent fiber stimulation in the presence of the agonist was not required for the potentiation and NMDA could elicit potentiation repeatedly in the same slice if sufficient time (about $30 \mathrm{~min}$ ) was allowed between applications. This agonist-induced potentiation is decremental and of a relatively short duration (10-30 $\mathrm{min}$ ) if compared with a high-frequency tetanus-induced potentiation of the synaptic response (Fig. 2). The present results indicate that presynaptic stimulation provides an essential component for development of LTP and that this form of information storage may be used under physiological conditions. The results are in agreement with previous studies demonstrating that glutamate and NMDA application does potentiate synaptic transmission in the hippocampus (Collingridge et al., 1983; Kauer et al., 1988).

\section{Pharmacology of the induction and expression of the LTP of EPSPs: actions of EAA receptor antagonists}

We next examined the contribution of NMDA and non-NMDA receptors to the induction and expression of LTP of EPSPs by using selective antagonists of NMDA and non-NMDA receptors. We first examined whether LTP of the AMPA receptormediated response requires NMDA receptor activation during tetanus. The selective and competitive antagonist of the NMDA subtype of glutamate receptors, APV (50-100 $\mu \mathrm{M})$, caused a small decrease in the amplitude of EPSP but prevented the induction of LTP when present at the time of tetanic stimulation (Fig. $7 ; n=5$ ). Moreover, in three of five cells, a small but prolonged depression occurred following perfusion with APV during high-frequency stimulation (Fig. 7A). Perfusion of spinal slices with APV after the potentiation has been established has no effect; that is, APV does not prevent expression of LTP of the non-NMDA receptor-mediated EPSP ( $n=2$; not shown).

Experimental evidence so far presented suggests that the currents initiated by the activation of NMDA receptors are necessary for the induction of LTP, but there is no information as to the contribution of the NMDA receptors to the expression of this effect. The present concept is that the expression of LTP appears to be dependent predominantly on AMPA receptormediated transmission. However, a pharmacologically isolated 
Figure 7. APV prevented the induction of LTP of EPSP in a normal slice. Effect of tetanic stimulation on EPSP recorded from the same SDH neuron (location shown in inset) in the presence of $50 \mu \mathrm{M} \operatorname{APV}(A)$ and $40 \mathrm{~min}$ following the removal of the drug $(C)$. At time 0 (arrow) the dorsal root was given three tetani at twice the intensity of the test stimulus (14 V, $0.05 \mathrm{msec})$. Above the graphs are displayed individual EPSPs obtained before $(A$, trace $I)$ and $6 \mathrm{~min}$ $(A$, trace 2$), 36 \mathrm{~min}(C$, trace 1$)$, and 52 min $(C$, trace 2$)$ after the removal of APV. Summarized data (mcan $\pm S E M$ ) showing the time course of the posttetanic changes of EPSPs in five cells (inset) in the presence of $50 \mu \mathrm{M}$ APV $(B)$ and $30-40 \mathrm{~min}$ following the removal of the drug (D). $A$ and $C, V_{m}=-76$ $\mathrm{mV}, 33-\mathrm{d}$-old rat; $B$ and $D, V_{m}^{m}=-64$ to $-75 \mathrm{mV}, 25-33$-d-old rats.
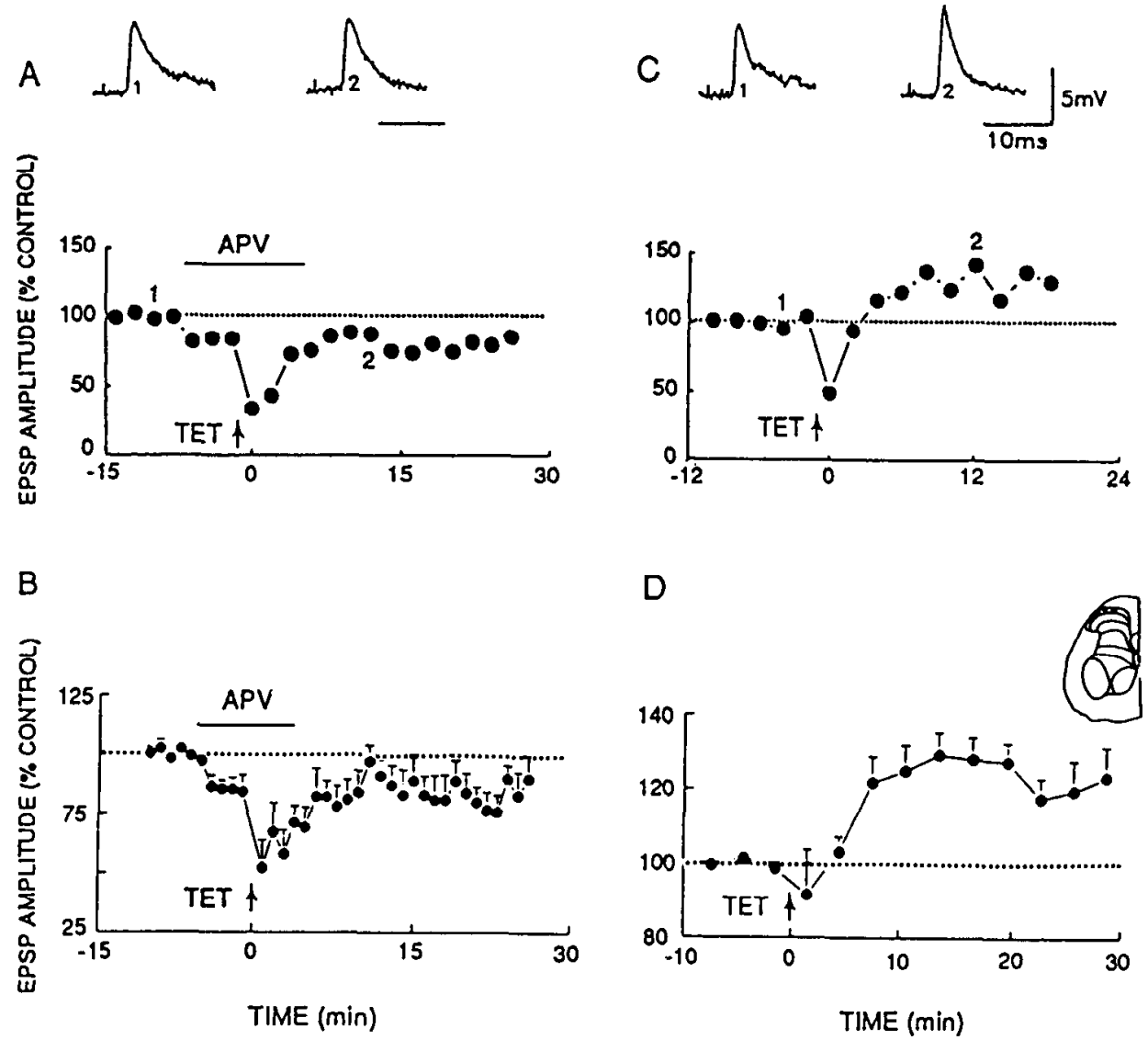

NMDA receptor-mediated synaptic response can undergo synapse-specific LTP in the hippocampus (Bashir et al., 1991; Xie et al., 1991). We now report that the potentiation of transmission at the primary afferent-DH cell synapses $(n=4)$ can also be expressed by the pharmacologically isolated NMDA receptormediated EPSP.

As mentioned above, synaptic responses in the DH region comprise an EPSP that appears to be mediated primarily by receptors of the non-NMDA class, but in addition has a small slow NMDA receptor-mediated synaptic component. When the AMPA receptor-mediated component of EPSP was blocked with bath application of CNQX $(10 \mu \mathrm{M})$ or NBQX $(2-10 \mu \mathrm{M})$, the NMDA receptor-mediated EPSPs were revealed either when slices were perfused with low- $\mathrm{Mg}^{2+}(100 \mu \mathrm{M})$ medium or when cells were depolarized to $-50 \mathrm{mV}$ in normal $\mathrm{Mg}^{2+}(1.2 \mathrm{mM})$. The cell depicted in Figure $8 A$ was recorded in the presence of $100 \mu \mathrm{M}$ external $\mathrm{Mg}^{2+}$ and $2 \mu \mathrm{M}$ NBQX. Superfusion of NBQX greatly reduced the amplitude of the EPSP. The residual synaptically evoked depolarization was enhanced by incrcasing the intensity of stimulation. After obtaining a baseline NMDA receptor-mediated response to test stimulation $(0.006 \mathrm{~Hz})$, tetanus was delivered and LTP of the synaptic response was recorded for more than $20 \mathrm{~min}$. At the end of the experiment, the potentiated response was reversibly blocked by APV $(100 \mu \mathrm{M}$; data not shown), the result indicating that the potentiation of EPSPs was mediated through NMDA receptor. LTP was ex- pressed in four DH cells, with an average increase of about $200 \%$ of control (Fig. $4 A$, Table 1).

\section{LTD of the monosynaptic EPSPs}

Here we report that an LTD of the amplitude of monosynaptic EPSPs can occur in neurons of the superficial laminae of DH of slices of the rat spinal cord after primary afferent fibers in DRs were stimulated with three tetani of $1 \mathrm{sec}$ duration, each delivered at $100 \mathrm{~Hz}$ and $10 \mathrm{sec}$ intervals. When the tetanus at the test intensity for single EPSP was employed, the depression of the amplitude and initial slope of EPSPs (Figs. $3 A, B ; 4 B$; Table 1) was observed in 11 of $49(22 \%)$ cells and persisted without signs of recovery for about $40 \mathrm{~min}$ after cessation of conditioning stimulation. However, when in nonresponsive cells we increased postsynaptic activation by raising the intensity of the tetanic stimulus (three times the test intensity), an LTD in 10 of $49(20 \%)$ cells lasting between $40 \mathrm{~min}$ and $4 \mathrm{hr}$ was observed. In seven neurons, the synaptic response displayed LTD when train was delivercd at test intensity for single EPSP, but LTP was induced when intensity of tetanic stimulation was increased. The magnitude of LTD varied in different cells, resulting in EPSPs that were between $90 \%$ and $20 \%$ of the size of test EPSPs during the control period. Compared with the corresponding values of EPSPs recorded prior to repetitive stimulation, this depression of EPSPs was statistically significant $(P$ $<0.05$; Fig. $4 B$ ). Figure 3 shows the time course and degree of 


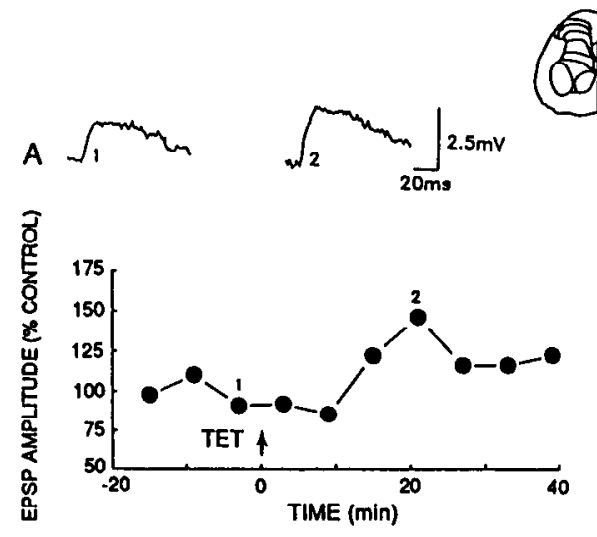

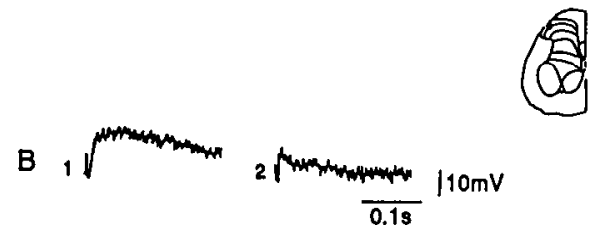

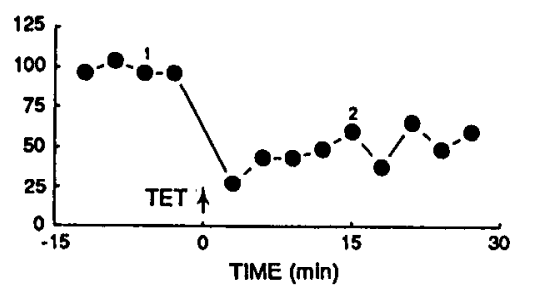

Figure 8. LTP and LTD of the NMDA receptor-mediated component of excitatory synaptic transmission. $A$, The graph shows the time course of LTP of NMDA receptor-mediated EPSP recorded intracellularly from an SG neuron (inset) in response to stimulation $(15 \mathrm{~V}, 0.1 \mathrm{msec})$ of a lumbar dorsal root. Perfusion medium contained 0.1 $\mathrm{mM} \mathrm{Mg}^{2+}$ and $2 \mu \mathrm{M}$ NBQX. At time 0 (arrow) the dorsal root was given three tetani $(100 \mathrm{~Hz}, 3 \times 1 \mathrm{sec})$ at the intensity of the test stimulus. $B$, In a different $S G$ neuron (inset) $0.1 \mathrm{mM} \mathrm{Mg} \mathbf{M g}^{2+}$ and 10 $\mu \mathrm{M} C N Q X$ were used to isolate the NMDA component of synaptic potential obtained by stimulation of DR ( 15 $\mathrm{V}, 0.1 \mathrm{msec})$. Tetanic stimulation (30 $\mathrm{V}, 0.1 \mathrm{msec}, 100 \mathrm{~Hz}, 3 \times 1 \mathrm{sec}$ ) was delivered at time 0 . Above the graphs are displayed individual EPSPs obtained before $(A, B$, trace 1$)$ and during LTP ( $A$, trace 2$)$ or LTD $(B$, trace 2$)$. $A, V_{m}=-76 \mathrm{mV}, 33$-d-old rat; $B, V_{m}$ $=-69 \mathrm{mV}, 22$-d-old rat. the prolonged depression of EPSPs following repetitive stimulation of the DR in a single DH cell (Fig. $3 C$ ) and in a group of nine neurons (Fig. 3D). As shown in Figure 3C, when the baseline measurements following trains were resumed, the first one or two responses were always depressed (or even abolished) even below the value attained during LTD. Although there was usually some recovery in response magnitude over the next several minutes, the EPSP amplitude always reached a plateau at a value that was significantly depressed as compared with the pretetanus control period.

It appears that the induction of LTD does not involve NMDA receptors, since the depressant effect was recorded in the superficial laminae DH neurons in the presence of the NMDA receptor antagonist APV $(n=4$; Fig. $7 A$; see also Fig. 10B). This finding is in agreement with previous studies of LTD in hippocampus (Stanton and Sejnowski, 1989) and visual cortex (Artola et al., 1990). LTD of primary afferent neurotransmission can be induced in the presence of $10 \mu \mathrm{M}$ CNQX or 2-10 $\mu \mathrm{M}$ NBQX, and in low- $\mathrm{Mg}^{2+}(100 \mu \mathrm{M})$ medium (Fig. $8 B$ ), indicating that the depression is expressed by both AMPA and NMDA receptors.

\section{Effects of neonatal capsaicin treatment on LTP and LTD of the evoked EPSPS}

Anatomical studies of the mammalian spinal $\mathrm{DH}$ have provided evidence that $C$ fibers give the major afferent input to the SG, whereas A $\delta$ fibers terminate predominantly in lamina I (Réthelyi, 1977; Light and Perl, 1979; Sugiura et al., 1986, 1989). In contrast, electrophysiological studies indicated that over 70\% of SG neurons received monosynaptic input from $\mathrm{A} \delta$ fiber afferents, only $5 \%$ from $C$ fibers, and about $20 \%$ received both A $\delta$ and $C$ fiber input (Yoshimura and Jessell, 1990). In order to examine the contribution of $\mathrm{A} \delta$ and $\mathrm{C}$ fiber inputs to the induction and expression of the long-lasting modulation of primary afferent transmission, we used neonatal treatment of rats with capsaicin, a neurotoxin known to cause degeneration of a large number of $C$ fibers (Jancsó et al., 1977). In 13 cells examined, we found the expression of LTP (Figs. 4A, 9A, 10A; Table 1) in six and LTD (Figs. $4 B, 9 B, 10 B$; Table 1) in seven SDH cells receiving monosynaptic input from primary afferent fibers following trains of high-frequency stimulation of DR at test or greater intensity as for single EPSP. In addition, three DH (laminae I-III) cells receiving polysynaptic input expressed LTP in slices obtained from capsaicin-treated rats. Figure $10 \mathrm{~A}$ illustrates the increase in the synaptic strength, as tested with single shock stimuli, following tetanic stimulation of primary afferent fibers at four times the test stimulus in a spinal slice obtained from the rat neonatally treated with capsaicin. Since the similar potentiating effect cannot be induced in the same cell in the presence of APV during tetanic stimulation (Fig. 10B), it appears that the process leading to the potentiation of presumable A $\delta$ fiber-mediated EPSP is related to the operation of the NMDA receptor-ion channel complex. The results obtained show that neonatal capsaicin treatment did not prevent the expression of LTP or LTD in DH neurons receiving predominantly $\mathrm{A} \delta$ afferent inputs.

\section{Effects of $G A B A_{A}$ receptor blockade on modulation of primary afferent neurotransmission}

Although there is little to suggest that inhibitory mechanisms contribute to the maintenance of synaptic LTP (Haas and Rose, 1982), there is evidence that its induction is affected by inhibitory influences (Douglas, 1978; Douglas et al., 1982; Wigström and Gustafsson, 1985). It is known that during high-frequency stimulation the cell remains depolarized for a sufficient time to enable activation of the NMDA receptor system. This is made possible, at least in part, by frequency-dependent depression of the synaptic inhibition caused by GABA feeding back and depressing its own release by an action on presynaptic $\mathrm{GABA}_{\mathrm{B}}$ autoreceptors (Davies et al., 1991). The latter finding demonstrated a role for $\mathrm{GABA}_{\mathrm{B}}$ receptors in synaptic plasticity (Collingridge and Singer, 1990).

In order to rule out possible involvement of polysynaptic inhibitory pathways in the mechanisms accounting for the prolonged EPSP potentiation and depression obscrved in this study, we blocked the $\mathrm{GABA}_{\mathrm{A}}$-ergic receptors in the spinal cord slice by bicuculline. We found that both the mono- and polysynaptic components of the EPSP of DH cells were markedly enhanced by bicuculline. The induction of LTP (Fig. 11 $A$ ) or LTD (Fig. $11 B$ ) is not abolished when the slice is perfused with bicuculline 

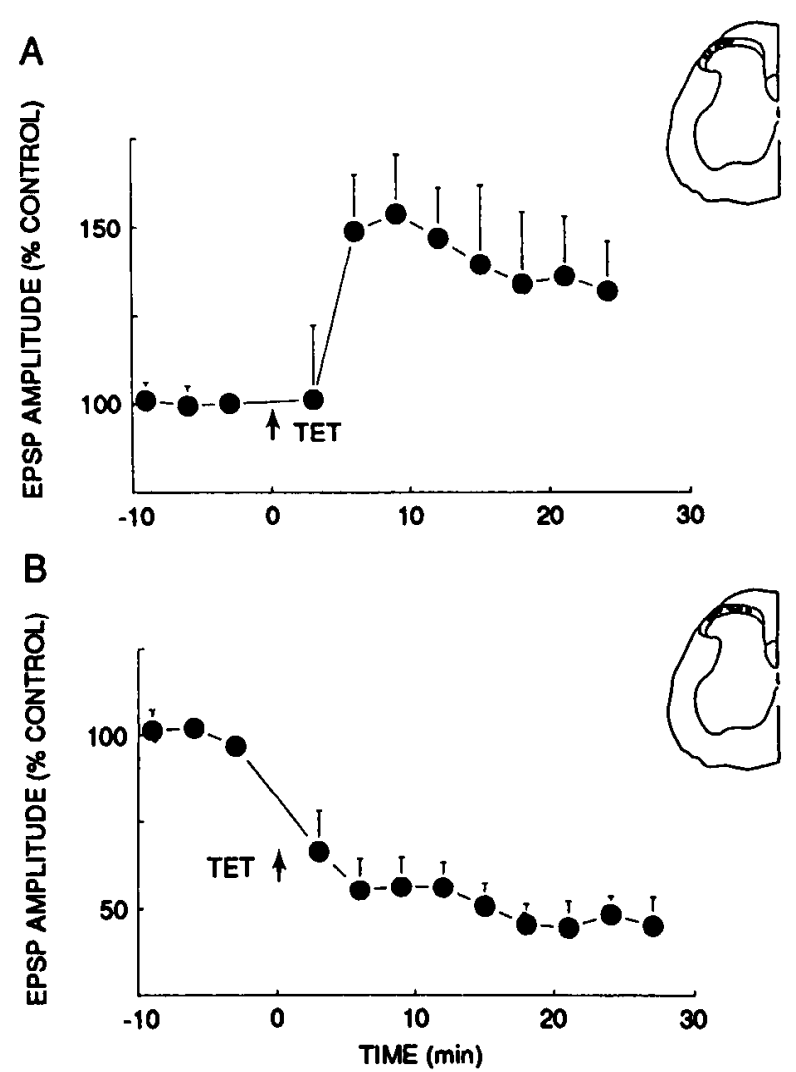

Figure 9. Long-lasting changes in synaptic efficacy are present in SG neurons of capsaicin-pretreated rats. $A$, Summarized data for six SG neurons (location shown in inset) obtained from capsaicin-pretreated rats, where tetanic stimulation $(100 \mathrm{~Hz}, 3 \times 1 \mathrm{sec})$ induced LTP of EPSPs evoked by low-frequency stimulation of dorsal roots. $B$, The time course of LTD of EPSPs recorded from seven different SG neurons (location shown in inset) in response to electrical stimulation of dorsal roots. Tetanus was delivered at time 0 (arrow). $V_{m}=-56$ to $-89 \mathrm{mV}$, 14-22-d-old rats.

(5-10 $\mu \mathrm{M}, n=13)$. However, as shown in Figure $11 \mathrm{~A}$, after a brief period of PTP the average monosynaptic EPSP amplitudes in the presence of bicuculline $(10 \mu \mathrm{M})$ were smaller when compared with values recorded in the absence of bicuculline. These differences were not statistically significant. LTD remained in- ducible in slices obtained from both intact $(n=3)$ and capsaicintreated $(n=4)$ rats in the presence of bicuculline $(5-10 \mu \mathrm{M})$.

\section{Facilitation and depression of polysynaptic EPSPS}

In addition to the presence of a high proportion of apparent monosynaptic EPSPs recorded from the DH neurons located in laminae I-III, electrical stimulation of primary afferent fibers (8-20 V pulses of $0.1 \mathrm{msec}$ duration) evoked polysynaptic EPSPs in 23 of 92 cells. These EPSPs have a variable latency and exhibit failures with high-frequency stimulation and after perfusion with solutions containing a high concentration of divalent cations. In this series of experiments we have confined our analysis of the effects of high-frequency stimulation of DRs to superficial DH neurons (laminac I-III) rccciving polysynaptic EPSPs based on these criteria. When three tetani of $1 \mathrm{sec}$ duration at $100 \mathrm{~Hz}$ at $10 \mathrm{sec}$ intervals, at test $(n=6)$ or greater intensity $(n=17)$, were delivered to the lumbar DR, the potentiation (Figs. $4 A$, $12 A$; Table 1) or depression (Figs. $4 B, 12 B$; Table 1 ) of polysynaptic EPSP amplitude resulted. In 17 (15 from intact, 2 from capsaicin-treated rats) of 23 cells with stable resting membrane potential and stable baseline EPSPs, the EPSP amplitude was significantly increased following the repetitive stimulation (Fig. $4 A$, Table 1). The duration of the potentiation ranged from 15 min to $4 \mathrm{hr}$. The potentiation considerably varied in amplitude, resulting in EPSPs that were between $120 \%$ and $240 \%$ of the amplitude of test EPSPs during the control period. Similar as for monosynaptic EPSPs, the induction of LTP of polysynaptic EPSPs requires the activation of NMDA receptor-gated conductance (Fig. 12B). In only six cells receiving polysynaptic inputs was an LTD obscrved.

\section{Discussion}

\section{Use-dependent changes in synaptic efficiency in rat $S D H$ in} vitro

In a variety of brain structures repetitive activation of synaptic connections can lead to LTP or LTD of excitatory synaptic transmission (Madison et al., 1991; Siegelbaum and Kandel, 1991; Johnston et al., 1992). However, the presence of the similar phenomena in the spinal cord has not until recently been reported (Cerne et al., 1991; Jiang and Randić, 1991; Randić et al., 1993; Rusin et al., 1993b). The major finding of the present
Figure 10. Effect of APV on the induction of LTP of EPSP in the slice obtained from capsaicin-pretreated rat: effect of tetanic stimulation on synaptic responses recorded from SDH ncuron (location shown in inset) in a slice obtained from a neonatally capsaicintreated rat in the absence $(A)$ and the presence $(B)$ of APV. Intensity of the tetanic stimulus was four times the test stimulus $(6.4 \mathrm{~V}, 0.1 \mathrm{msec})$. Above the graphs are displayed individual EPSPs obtained before $(A, B$, trace $I)$ and during $\operatorname{LTP}(A$, trace 2$)$ and $10 \mathrm{~min}$ after removal of APV $(B$, trace 2$)$. Values are expressed as percentage of response amplitude measured before the beginning of APV perfusion. $V_{m}=-70 \mathrm{mV}$, 25-d-old rat.
A<smiles>CCCCC</smiles><smiles>C1CCCCCC1</smiles>

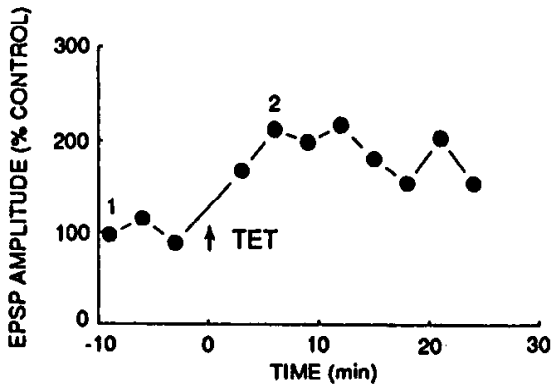<smiles>[B][14CH]1CC1C</smiles><smiles>C[Si](C)(C)[Al]CC1CC1</smiles>

बิ 


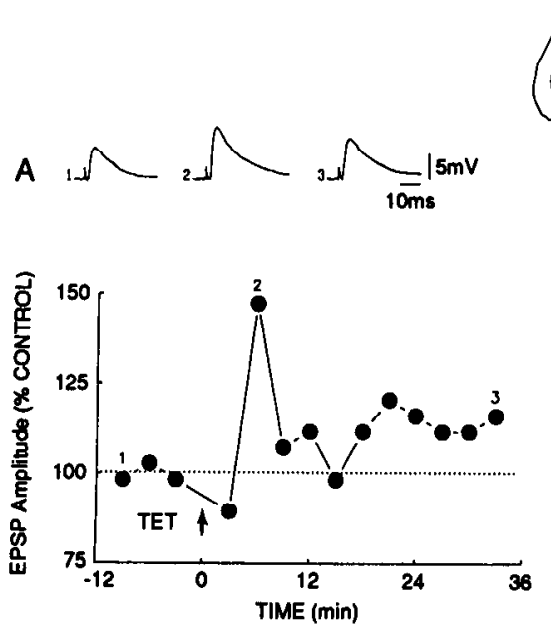

Figure 11. LTP and LTD of EPSPs do not require activation of the $\mathrm{GABA}_{\mathrm{A}}$ inhibitory system. $A$, In a slice that was constantly superfused with a recording solution containing bicuculline $(10 \mu \mathrm{M})$, dorsal root stimulation $(8 \mathrm{~V}, 0.1 \mathrm{msec})$ evoked EPSPs in a DH neuron (the traces above the graph). Tetanic stimulation $(100 \mathrm{~Hz}, 3 \times 1 \mathrm{sec})$ of twice the test stimulus intensity induced a potentiation of EPSP as shown in the graph. $B$, In another neuron superfused with bicuculline $(10 \mu \mathrm{M})$ EPSPs were induced by stimulation of a dorsal root $(10 \mathrm{~V}, 0.1 \mathrm{msec})$. Tetanic stimulation with the test stimulus intensity evoked a prolonged depression of the fast synaptic transmission. Above the graphs are displayed individual EPSPs obtained before $(A, B$, trace 1$)$ and during LTP $(A$, traces 2,3$)$ or LTD $(B$, trace 2). $A, V_{m}=-85 \mathrm{mV}, 32$-d-old rat; $B$. $V_{m}, 18$-d-old rat.

study is that brief repetitive activation of primary afferent synapses with neurons in the superficial laminae of DH (laminae I-III; Rexed, 1951) of the rat spinal cord results in a substantial increase or decrease in synaptic strength that can last from 20 min to more than an hour. The results obtained in intact and neonatally capsaicin-treated rats suggest that these prolonged changes in synaptic efficiency occur in a high-proportion of $\mathrm{DH}$ neurons receiving small-diameter primary afferent fiber inputs (Réthelyi, 1977; Light and Perl, 1979; Sugiura et al., 1986, 1989). However, the transverse slice preparation, which retained only 3-6 $\mathrm{mm}$ of attached dorsal roots, did not permit us reliable measurements of conduction velocity of the stimulated primary afferent fibers in order to conclude which fiber groups were responsible for the EPSPs in each case. Because of this problem, analysis of the conduction velocity of primary afferent fibers responsible for LTP or LTD of monosynaptic EPSPs should be undertaken in the future using the longitudinal slice preparation having intact dorsal roots and dorsal root ganglia attached.

The EPSP that is seen to be modified is mediated by AMPA receptors since it is blocked by AMPA antagonists, such as NBQX (Sheardown et al., 1990; Cerne et al., 1991), and is little affected by NMDA antagonist APV (Gerber and Randić, 1989; Yoshimura and Jessell, 1990). These results agree with pub- lished data showing that the AMPA receptor plays a key role in mediating expression of both forms of plasticity. Thus, the upregulation of AMPA receptors is responsible for LTP expression in the CA1 region of the hippocampus (Davies et al., 1989) and the AMPA receptors' downregulation is responsible for LTD induction in the cerebellum (Linden et al., 1991). In addition, we now report that the potentiation of transmission at the primary afferent-DH cell synapses can also be expressed by the pharmacologically isolated NMDA receptor-mediated EPSP. This finding is in agreement with previous reports showing that the NMDA receptor-mediated synaptic response can also undergo synapse-specific LTP in the hippocampus (Bashir et al., 1991; Xie et al., 1991).

An interesting finding of the present study was that in a given cell the same tetanic stimulation can induce either LTP or LTD of the synaptic response depending on the level of membrane potential of the postsynaptic neuron during the tetanic stimulation. Moreover, this result provides a direct proof that the processes generating LTP or LTD of the primary afferent neurotransmission both depend on postsynaptic membranc potential and that they have different thresholds. Previous studies have shown that in neocortex the same afferent activity can lead either to LTP or LTD depending on the level of postsynaptic
A

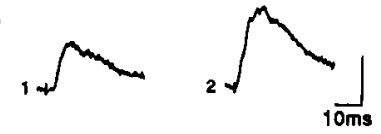

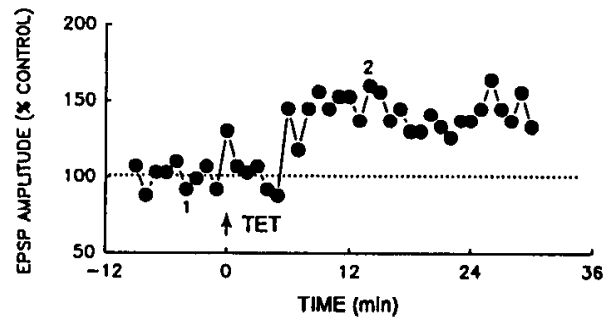

B
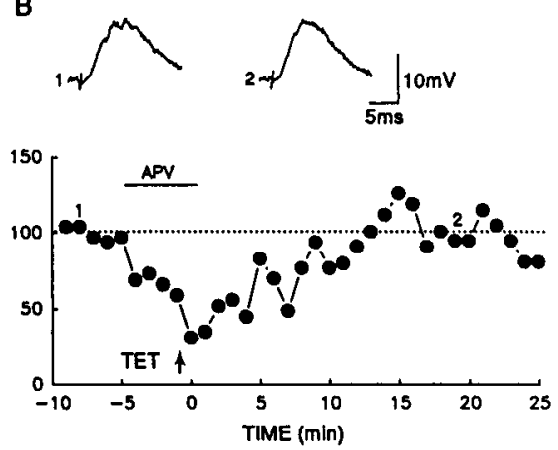

Figure 12. APV prevented the induction of the potentiation of polysynaptic EPSPs in the SDH. $A$, The graph shows the time course of a long-lasting potentiation of a polysynaptic EPSP recorded intracellularly from an SDH neuron in response to electrical stimulation $(5 \mathrm{~V}$, $0.05 \mathrm{msec}$ ) of a lumbar dorsal root. At time 0 (arrow) the dorsal root was given three tetani (at twice the intensity of the test stimulus) of $1 \mathrm{sec}$ duration, each at $100 \mathrm{~Hz}$ and $10 \mathrm{sec}$ intervals. $B$, APV $(50 \mu \mathrm{M})$ prevented the induction of the potentiation in the same neuron. Above the graphs are displayed individual EPSPs obtained before $(A, B$, trace $I)$ and during LTP $(A$, trace 2$)$ and $18 \mathrm{~min}$ after removal of APV $(B$, trace 2$)$. $V_{m}$ $=-69 \mathrm{mV}, 30$-d-old rat. 
depolarization obtained during the tetanus. If depolarization is strong enough to reach the activation threshold for NMDA receptor-gated channels, the tetanus causes LTP; if depolarization remains below this level, LTD is induced (Artola et al., 1990). This suggests as one variable a postsynaptic voltagedependent signal and, together with recent results of the same group (Bröcher et al., 1992), raises the possibility that $\mathrm{Ca}^{2+}$ may actually serve as a trigger for both LTP and LTD.

\section{LTP of synaptic responses in the rat $D H$ neurons following repetitive activation of primary afferents}

Although a great deal is known about LTP in hippocampus and cerebral cortex (Collingridge and Singer, 1990; Madison et al., 1991; Siegelbaum and Kandel, 1991; Johnston et al., 1992), the cellular mechanism(s) underlying this phenomenon in the superficial laminae of SDH has yet to be elucidated.

There is a general consensus that in the Schaffer collateralcommissural pathway in the CAl region of the hippocampus the induction of LTP involves processes located in the postsynaptic cell. The induction of LTP is presently thought to require both activation of NMDA receptors by synaptically released glutamate (Collingridge et al., 1983) and depolarization of the postsynaptic membrane (Gustafsson and Wigström, 1986). The biochemical cascades that lead to the associative form of LTP in cortical structures appear to be triggered by a surge of free $\mathrm{Ca}^{2+}$ ions in the postsynaptic neuron after activation of NMDA receptor-gated $\mathrm{Ca}^{2+}$ conductances (Mayer et al., 1984; Nowak et al., 1984) and voltage-dependent $\mathrm{Ca}^{2+}$ channels (Madison et al., 1991; Siegelbaum and Kandel, 1991; Johnston et al., 1992). $\mathrm{Ca}^{2+}$ influx is thought to lcad to protein phosphorylation, probably initiated by $\mathrm{Ca}^{2+} /$ calmodulin kinase II (protein kinase B) and $\mathrm{Ca}^{2+}$ phospholipid-dependent kinase (protein kinase $\mathrm{C}$ ) (Madison et al., 1991; Siegelbaum and Kandel, 1991). Moreover, studies of LTP in the CAl region of the hippocampus have revealed that although LTP is induced postsynaptically, the maintenance of LTP may be, at least in part, presynaptic due to a long-lasting enhancement of transmitter release (Dolphin et al., 1982; Bliss et al., 1986; Davies et al., 1989; Bekkers and Stevens, 1990; Hess and Gustafsson, 1990; Malinow and Tsien, 1990; Tsien and Malinow, 1990; Malinow, 1991) and a delayed postsynaptic increase in the number or sensitivity of postsynaptic AMPA subtypes of glutamate receptor (Davies et al., 1989). In agreement with this model, glutamate and NMDA application was found to potentiate synaptic transmission in the hippocampus (Kauer et al., 1988) and, in the present study, in the superficial DH region of the spinal cord (Cerne et al., 1991).

As shown earlier (Schneider and Perl, 1988; Gerber and Randić, 1989; Yoshimura and Jessell, 1990), and in the present study, during low-frequency transmission NMDA receptors contribute little to a subthreshold, presumably monosynaptic EPSP recorded from a neuron in the superficial laminae of the spinal DH at its resting membrane potential in a standard physiological medium. However, during high-frequency transmission the cell remains depolarized for a sufficient time to enable activation of the NMDA receptor system (Collingridge et al., 1988a,b; Gerber and Randić, 1989; Gerber et al., 1991). We have demonstrated in the present study that activation of NMDA receptors is a requirement for the induction of the long-lasting enhancement of EPSPs of DH neurons since APV, an NMDA receptor antagonist, blocks this process. Moreover, whereas perfusion of APV during high-frequency stimulation (the induction phase) blocks the potentiation, perfusion of APV after the potentiating effect has been established has no effect; that is, APV does not prevent expression of the enhancement of EPSP.

Although we cannot at present be certain whether pre- or postsynaptic factors, or both, are responsible for expression of a positive amplitude modulation of monosynaptic EPSPs in DH neurons following high-frequency stimulation, two findings obtained in our work provide evidence suggesting the involvement of presynaptic factors. First, we have demonstrated a sustained relative increase in the amount of endogenous glutamate and aspartate released into the spinal slice superfusate following highfrequency stimulation of primary afferent fibers in DRs (Randić et al., 1993; Rusin et al., 1993b). This result is in agreement with the findings of Bliss et al. (1986) that initially provided evidence for enhanced presynaptic rclcasc of glutamate and aspartate during LTP in the dentate gyrus of anesthetized rats. Second, the present study has revealed that not only AMPA receptor-mediated EPSP, but also a pharmacologically isolated NMDA receptor-mediated synaptic response can undergo LTP. LTP of NMDA receptor-mediated transmission in hippocampal slice has been previously reported (Bashir et al., 1991; Xie et al., 1991).

Although the results mentioned above suggest that the maintenance of positive amplitude modulation of EPSPs following high-frequency stimulation depends on properties of the presynaptic terminals, they do not rule out a contribution from other mechanisms. These include increase in sensitivity of $\mathrm{DH}$ neurons to locally applied AMPA receptor ligands (Davies et al., 1989; Cerne and Randić, 1992; Cerne et al., 1992), activation of parallel neural networks affecting transmission at either preor postsynaptic levels, co-release of EAAs and peptides from terminals (Loechner et al., 1990) resulting in the modulation of the amount of released transmitter (Kangrga and Randić, 1990) or sensitivity of postsynaptic EAA receptors (Randic et al., 1990; Rusin and Randić, 1991; Rusin et al., 1992, 1993a,b; Kolaj et al., 1993), and activation of second messenger systems (Gerber et al., 1989; Cerne et al., 1992, 1993). At present we have no evidence for or against the involvement of any of these mechanisms.

It has been known for some time that $\mathrm{C}$ fibers, which provide major primary afferent input to SG neurons (Réthelyi, 1977; Light and Perl, 1979; Sugiura et al., 1986, 1989), have a unique capacity to produce activity-dependent alterations in the excitability of neurons in the spinal cord. Two such afferent-induced excitability changes have been described in vivo. The first is the phenomenon of "windup," a progressive increase in the number of action potentials elicited per stimulus that occurs in $\mathrm{DH}$ neurons when $\mathrm{C}$ fibers are repetitively stimulated at frequencies of $>0.2 \mathrm{~Hz}$ (Mendell and Wall, 1965; Mendell, 1966; Schouenberg and Sjölund, 1983). The second is prolonged increase in the excitability of spinal neurons following a brief $C$ fiber strength conditioning stimulation (Woolf; 1983; Woolf and Wall, 1986; Cook et al., 1987; Thompson et al., 1990). Both phenomena, in addition to the enhancement of EPSPs described in the present study, are of interest in relation to the mechanisms involved in the generation of postinjury pain hypersensitivity.

\section{$L T D$ of synaptic responses in the rat DH neurons following repetitive activation of primary afferents}

Besides LTP of excitatory synaptic transmission, one mechanism that has recently received much attention is associative LTD of synaptic transmission. Like LTP, LTD also provides a means for regulating the strength of synaptic connections in the 
mammalian brain and spinal cord. LTD has been extensively studied in the cerebellum (Ito and Kano, 1982; Crepel and Krupa, 1988; Ito, 1989; Linden et al., 1991), the hippocampus (Stanton and Sejnowski, 1989; Pockett et al., 1990; Sejnowski, 1991; Dudek and Bear, 1992), and the cerebral cortex (Artola et al., 1990; Hirsch and Crepel, 1990; Bröcher et al., 1992). Prolonged, the low-frequency (up to $5 \mathrm{~Hz}$ ) depression of synaptic transmission between dorsal root afferents and $\alpha$-motoneurons was recently described in the in vitro hemisected spinal cord preparation isolated from neonatal (6-8-d-old) rats (Lev-Tov and Pinco, 1992), and during higher-frequency $(18 \mathrm{~Hz})$ stimulation of single group Ia fibers in motoneurons of anesthetized cats (Koerber and Mendell, 1991).

An important finding of this study is that high-frequency repetitive stimulation of the primary afferent input to neurons in the superficial laminae of the spinal DH, including SG cclls, can lead to a reliable and long-lasting depression of synaptic transmission manifested as a significant decrease in EPSP amplitude. The exact cellular mechanism(s) underlying this depression process has yet to be elucidated. In agreement with the results obtained in the visual cortex (Artola et al., 1990), evidence has been obtained in our study that LTD induction at least in part depends on postsynaptic mechanism. It requires a critical level of membrane potential but does not depend on NMDA or GA$\mathrm{BA}_{\mathrm{A}}$ receptor activation. Thus, we show that LTD of primary afferent neurotransmission can be induced in the presence of APV, the finding that excluded a possible involvement of postsynaptic NMDA receptors in the induction mechanism. This result is in agreement with previous studies of homosynaptic LTD in the CA1 region of hippocampus (Stanton and Sejnowski, 1989) and in the rat visual cortex (Artola et al., 1990). However, it differs from the results of Goldman et al. (1990) showing failure to reverse LTP by coupling sustained presynaptic activity and NMDA receptor blockade. In this context, it should be noted that homosynaptic LTD in area CA1 of hippocampus was recently described in response to low-frequency stimulation (1$3 \mathrm{~Hz}$ ) of the Schaeffer collaterals (Dudek and Bear, 1992) and the suggestion was made that it can be triggered by prolonged NMDA receptor activation that is below the threshold for inducing synaptic potentiation. The involvement of prolonged changes in the passive properties of the $\mathrm{DH}$ neurons due to activation of postsynaptic inhibitory pathways by DR stimulation has been excluded by the findings that the prolonged depression of EPSP was not altered by blockade of the postsynaptic $\mathrm{GABA}_{\mathrm{A}}$ receptors in the spinal cord slices with bicuculline.

Another postsynaptic mechanism that might contribute to the prolonged depression of EPSPs is desensitization of the AMPA type of glutamate receptors in the postsynaptic membrane (Linden et al., 1991). Recent studies demonstrated that the processes underlying the induction of LTD in neocortex (Bröcher et al., 1992) and cerebellum (Sakurai, 1990) are located postsynaptically and that they depend on intracellular $\mathrm{Ca}^{2+}$ concentration. Changes in $\left[\mathrm{Ca}^{2+}\right]_{i}$ could result from activation of voltage-dependent $\mathrm{Ca}^{2+}$ channels or from activation of metabotropic glutamate receptors. A recent report has suggested a role for a novel second messenger, nitric oxide (NO), in LTD induction (Shibuki and Okada, 1991).

As to the presynaptic mechanism, the prolonged depression of EPSPs may be due to a prolonged decrease in transmitter release. There are at least two presynaptic mechanisms that might decrease the release of excitatory transmitter from the activated primary afferents: (1) activation of presynaptic inhibitory pathways (Nicoll and Alger, 1979; Nicoll et al., 1990), and (2) reduced efficacy of the transmitter release machinery of the synapse following high-frequency stimulation of DRs. The involvement of $\mathrm{GABA}_{\mathrm{A}}$-mediated presynaptic inhibition in the prolonged synaptic depression is ruled out by the finding that blockade of the $\mathrm{GABA}_{\mathrm{A}}$ receptors by a specific antagonist bicuculline did not affect the level and time course of the prolonged depression of EPSPs in SDH cells.

There are several possible explanations for our results that do not involve plasticity of stimulated synapses. For example, it is possible that the high-frequency stimulation produces excitotoxic damage in the target neurons or some generalized loss of postsynaptic excitability or damage or fatigue of the stimulated inputs. If this were the case then repeated stimulation in the same cell would be expected to always produce LTD, irrespective of the intensity of the stimulus employed and membrane potential at which tetanus was delivered. However, we occasionally observed $(n=7)$ that the synaptic response displayed LTD when train was delivered at test intensity for a single EPSP, but LTP was induced when intensity of tetanic stimulation was increased. In addition, the depressed input could still undergo LTP after applying identical high-frequency stimulus at a more depolarized level. Although these observations do not rule out presynaptic damage or depletion of transmitter, they do indicate that depressed synapses are sufficiently viable to support the mechanisms that give rise to LTP.

\section{References}

Artola A, Bröcher S, Singer W (1990) Different voltage-dependent thresholds for inducing long-term depression and long-term potentiation in slices of rat visual cortex. Nature 347:69-72.

Ascher P, Nowak L (1987) Electrophysiological studies of NMDA receptors. Trends Neurosci 10:284-288.

Bashir ZI, Alford S, Davies SN, Randall AD, Collingridge GL (1991) Long-term potentiation of NMDA receptor-mediated synaptic transmission in the hippocampus. Nature 349:156-158.

Bckkers JM, Stevens CF (1990) Presynaptic mechanism for long-term potentiation in the hippocampus. Nature 346:724-729.

Bliss TVP, Douglas RM, Errington ML, Lynch MA (1986) Correlation between long-term potentiation and release of endogenous amino acids from dentate gyrus of anaesthetized rats. J Physiol (Lond) 377: 391-408.

Bröcher S, Artola A, Singer W (1992) Intracellular injection of $\mathrm{Ca}^{2+}$ chelators blocks induction of long-term depression in rat visual cortex Proc Natl Acad Sci USA 89:123-127.

Burke RE (1987) Synaptic efficacy and the control of neuronal inputoutput relations. Trends Neurosci 10:42-45.

Cerne R, Randić M (1992) Modulation of AMPA and NMDA responses in rat spinal dorsal horn neurons by trans-1-aminocyclopentane-1,3-dicarboxylic acid. Neurosci Lett 144:180-184.

Cerne R, Jiang MC, Randić M (1991) Long-lasting modification in synaptic efficacy at primary afferent synapses with neurons in rat superficial spinal dorsal horn. Soc Neurosci Abstr 17:1331.

Cerne R, Jiang MC, Randić M (1992) Cyclic adenosine 3'5'-monophosphate potentiates excitatory amino acid and synaptic responses of rat spinal dorsal horn neurons. Brain Res 596:111-123.

Cerne R, Rusin KI, Randić M (1993) Enhancement of the $N$-methyl$\mathrm{D}$-aspartate response in spinal dorsal horn neurons by cAMP-dependent protein kinase. Neurosci Lett, in press.

Collingridge GL, Singer W (1990) Excitatory amino acid receptors and synaptic plasticity. Trends Pharmacol Sci 11:290-296.

Collingridge GL, Kehl SJ, McLennan H (1983) Excitatory amino acids in synaptic transmission in the Schaffer collateral-commissural pathway of the rat hippocampus. J Physiol (Lond) 334:33-46.

Collingridge GL, Herron CE, Lester RAJ (1988a) Synaptic activation of $N$-methyl-D-aspartate receptors in the Schaffer collateral-commissural pathway of rat hippocampus. J Physiol (Lond) 399:283-300.

Collingridge GL, Herron CE, Lester RAJ (1988b) Frequency-depen- 
dent $N$-methyl-D-aspartate receptor-mediated synaptic transmission in rat hippocampus. J Physiol (Lond) 399:301-312.

Cook AJ, WoolfCJ, Wall PD, McMahon SB (1987) Dynamic receptive field plasticity in rat spinal cord dorsal horn following C-primary afferent input. Nature 325:151-153.

Crepel F, Krupa M (1988) Activation of protein kinase C induces a long-term depression of glutamate sensitivity of cerebellar Purkinje cells. An in vitro study. Brain Res 458:397-401.

Dale N, Roberts A (1985) Dual-component amino-acid-mediated synaptic potentials: excitatory drive for swimming in Xenopus embryos. J Physiol (Lond) 363:35-59.

Davies CH, Stanley SJ, Pozza MF, Collingridge G (1991) GABA autoreceptors regulate the induction of LTP. Nature 349:609-611.

Davies JD, Francis AL, Jones AW, Watkins JC (1981) 2-Amino-5phosphonovalerate is potent and selective antagonist of amino acidinduced and synaptic excitation. Neurosci Lett 21:77-82.

Davies SN, Lester RAJ, Reymann KG, Collingridge GL (1989) Temporally distinct pre- and postsynaptic mechanisms maintain longterm potentiation. Nature 338:500-503.

Dolphin AC, Errington ML, Bliss TVP (1982) Long-term potentiation of the perforant path in vivo is associated with increased glutamate release. Nature 297:496-498.

Douglas RM (1978) Heterosynaptic control over synaptic modification in the dentate gyrus. Soc Neurosci Abstr 4:470.

Douglas RM, Goddard GV, Riives M (1982) Inhibitory modulation of long term potentiation: evidence for a postsynaptic locus of control. Brain Res 240:259-272.

Dudek SM, Bear KF (1992) Homosynaptic long-term depression in area CAl of hippocampus and effects of $N$-methyl-D-aspartate receptor blockade. Proc Natl Acad Sci USA 89:4363-4367.

Forsythe ID, Westbrook GL (1988) Slow excitatory postsynaptic currents mediated by $N$-methyl-D-aspartate receptors on cultured mouse central neurones. J Physiol (Lond) 396:515-533.

Gerber G, Randić M (1989) Excitatory amino acid-mediated components of synaptically evoked input from dorsal roots to deep dorsal horn neurons in the rat spinal cord slice. Neurosci Lett 106:211-219.

Gerber G, Kangrga I, Ryu PD, Larew JSA, Randić M (1989) Multiple effects of phorbol esters in the rat spinal dorsal horn. J Neurosci 9:3606-3617.

Gerber G, Cerne R, Randić M (1991) Participation of excitatory amino acid receptors in the slow excitatory synaptic transmission in rat spinal dorsal horn. Brain Res 561:236-251.

Goldman RS, Chavez-Noriega LE, Stevens CF (1990) Failure to reverse long-term potentiation by coupling sustained presynaptic activity and $N$-methyl-D-aspartate receptor blockade. Proc Natl Acad Sci USA 87:7165-7169.

Gustafsson B, Wigström H (1986) Hippocampal long-lasting potentiation produced by pairing single volleys and brief conditioning tetani evoked in separate afferents. J Neurosci 6:1575-1582.

Haas HL, Rose G (1982) Long term potentiation of excitatory synaptic transmission in the rat hippocampus: the role of inhibitory processes. J Physiol (Lond) 329:541-552.

Hess G, Gustafsson B (1990) Changes in field excitatory postsynaptic potential shape induced by tetanization in the CA1 region of the guinea pig hippocampal slice. Neuroscience 37:61-69.

Hirsch JC, Crepel F (1990) Use-dependent changes in synaptic efficacy in rat prefrontal neurons in vitro. J Physiol (Lond) 427:31-49.

Honoré T, Davies SN, Drejer J, Fletcher EJ, Jacobsen P, Lodge D, Nielsen FE (1988) Quinoxalinediones: potent, competitive nonNMDA glutamate receptor antagonists. Science 241:701-703.

Ito M (1989) Long-term depression. Annu Rev Neurosci 12:85-102.

Ito M, Kano M (1982) Long-lasting depression of parallel fiber-Purkinje cell transmission induced by conjunctive stimulation of parallel fibers and climbing fibers in the cerebellar cortex. Neurosci Lett 33: 253-258.

Jahr CE, Jessell TM (1985) Synaptic transmission between dorsal root ganglion and dorsal horn neurons in culture: antagonism of monosynaptic excitatory postsynaptic potentials and glutamate excitation by kynurenate. J Neurosci 5:2281-2289.

Jancsó G, Kiraly E, Jancsó-Gábor A (1977) Pharmacologically induced selective degeneration of chemosensitive primary sensory neurones. Nature 270:741-743.

Jiang MC, Randić M (1991) Long-lasting modification in synaptic efficacy at primary afferent synapses with neurons in rat superficial spinal dorsal horn. Third IBRO World Congr Neurosci Abstr, p 307
Johnston D, Williams S, Jaffe D, Gray R (1992) NMDA-receptor independent long-term potentiation. Annu Rev Physiol 54:489-505.

Kangrga I, Randić M (1990) Tachykinins and calcitonin gene-related peptide enhance release of endogenous glutamate and aspartate from the rat spinal dorsal horn slice. J Neurosci 10:2026-2038.

Kangrga I, Randic M (1991) Outflow of endogenous aspartate and glutamate from the rat spinal dorsal horn in vitro by activation of low- and high-threshold primary afferent fibers. Modulation by $\mu$-opioids. Brain Res 553:347-352.

Kauer JA, Malenka RC, Nicoll RA (1988) NMDA application potentiates synaptic transmission in the hippocampus. Nature 334:250252.

Koerber HR, Mendell LM (1991) Modulation of synaptic transmission at Ia afferent fiber connections on motoncurons during high-frequency stimulation: role of postsynaptic target. J Neurophysiol 65:590-597.

Kolaj M, Cerne R, Randić M (1993) Modulation of AMPA and NMDA responses in acutely isolated rat spinal dorsal horn neurons by dynorphin A. Neurosci Lett, in press.

Lev-Tov A, Pinco M (1992) In vitro studies of prolonged synaptic depression in the neonatal rat spinal cord. J Physiol (Lond) 447:149169.

Light AR, Perl ER (1979) Spinal termination of functionally identified primary afferent neurons with slowly conducting myelinated fibers. J Comp Neurol 186:133-150.

Linden DJ, Dickinson MH, Smeyne M, Connor JA (1991) A longterm depression of AMPA currents in cultured cerebellar Purkinje neurons. Neuron 7:81-89.

Loechner KJ, Azhderian EM, Dreyer R, Kaczmarek LK (1990) Progressive potentiation of peptide release during a neuronal discharge. J Neurophysiol 63:738-744.

Madison DV, Malenka RC, Nicoll RA (1991) Mechanisms underlying long-term potentiation of synaptic transmission. Annu Rev Neurosci 14:379-397.

Malinow R (1991) Transmission between pairs of hippocampal slice neurons: quantal levels, oscillations, and LTP. Science 252:722-724.

Malinow R, Tsien RW (1990) Presynaptic enhancement shown by whole-cell recordings of long-term potentiation in hippocampal slices. Nature 346:177-180.

Mayer MI, Miller R J (1991) Fxcitatory amino acid receptors, second messengers and regulation of intracellular $\mathrm{Ca}^{2+}$ in mammalian neurons. In: The pharmacology of excitatory amino acids. A special report (Lodge E, Collingridge G, eds), pp 36-42. Cambridge: Elsevier.

Mayer ML, Westbrook GL (1987) The physiology of excitatory amino acids in the vertebrate central nervous system. Prog Neurobiol 28: $197-276$.

Mayer ML, Westbrook GL, Guthrie PB (1984) Voltage-dependent block by $\mathrm{Mg}^{2+}$ of NMDA responses in spinal cord neurones. Nature 309:261-263.

Mendell LM (1966) Physiological properties of unmyelinated fiber projection to the spinal cord. Exp Neurol 16:316-332.

Mendell LM (1984) Modifiability of spinal synapses. Physiol Rev 64: 260-324.

Mendell LM, Wall PD (1965) Responses of single dorsal cord cells to peripheral cutaneous unmyelinated fibres. Nature 206:97-99.

Murase K, Randić M (1983) Electrophysiological properties of rat spinal dorsal horn neurones in vitro: calcium-dependent action potentials. J Physiol (Lond) 334:141-153.

Murase K, Randić M (1984) Actions of substance $P$ on rat spinal dorsal horn neurones. J Physiol (Lond) 346:203-217.

Nicoll RA, Alger BE (1979) Presynaptic inhibition: transmitter and ionic mechanisms. Int Rev Neurobiol 21:217-258.

Nicoll RA, Malenka RC, Kauer JA (1990) Functional comparison of neurotransmitter receptor subtypes in mammalian central nervous system. Physiol Rev 70:513-565.

Nowak LM, Bregestovski P, Ascher P, Herbet A, Prochiantz A (1984) Magnesium gates glutamate-activated channels in mouse central neurones. Nature 307:462-465.

Pockett S, Brookes NH, Bindman LJ (1990) Long-term depression at synapses in slices of rat hippocampus can be induced by bursts of postsynaptic activity. Exp Brain Res 80:196-200.

Randić M, Hećimović H, Ryu PD (1990) Substance P modulates glutamate-induced currents in acutely isolated rat spinal dorsal horn neurones. Neurosci Lett 1 17:74-80.

Randić M, Jiang MC, Rusin KI, Cerne R, Kolaj M (1993) Interactions between excitatory amino acids and tachykinins and long-term changes 
of synaptic responses in the rat spinal dorsal horn. In: Proceedings of the symposium on neuropeptides, nociception and pain, in press. Mainz: German Academy of Sciences.

Réthelyi M (1977) Preterminal and terminal axon arborizations in the substantia gelatinosa of cat's spinal cord. J Comp Neurol 172:511528.

Rexed B (1951) The cytoarchitectonic organization of the spinal cord in the rat. J Comp Neurol 96:415-466.

Rusin KI, Randić M (1991) Modulation of NMDA-induced currents by $\mu$-opioid receptor agonist DAGO in acutely isolated rat spinal dorsal horn neurons. Neurosci Lett 124:208-212.

Rusin KI, Ryu PD, Randić M (1992) Modulation of excitatory amino acid responses in rat dorsal horn neurons by tachykinins. J Neurophysiol 68:265-286.

Rusin KI, Bleakman D, Chard PS, Randić M, Miller RJ (1993a) Tachykinins potentiate $N$-methyl-D-aspartate responses in acutely isolated neurons from the dorsal horn. J Neurochem 60:952-960.

Rusin KI, Jiang MC, Cerne R, Randić M (1993b) Interactions between excitatory amino acids and tachykinins in the rat spinal dorsal horn. Brain Res Bull 30:329-338.

Sakurai M (1990) Calcium is an intracellular mediator of the climbing fiber in induction of cerebellar long-term depression. Proc Natl Acad Sci USA 87:3383-3385.

Schneider SP, Perl ER (1988) Comparison of primary afferent and glutamate excitation of neurons in the mammalian spinal dorsal horn. J Neurosci 8:2062-2073.

Schoepp D, Bockaert J, Sladeczek F (1991) Pharmacological and functional characteristics of metabotropic excitatory amino acid receptors. In: The pharmacology of excitatory amino acids. A special report (Lodge E, Collingridge G, eds), pp 74-81. Cambridge: Elsevier.

Schouenberg J, Sjölund BH (1983) Activity evoked by A- and C-afferent fibers in rat dorsal horn neurons and its relation to a flexion reflex. J Neurophysiol 50:1108-1121.

Sejnowski T (1991) Synaptic mechanisms for long-term depression. Curr Biol 1:38-42.

Sheardown MJ, Nielsen EØ, Hansen AJ, Jacobsen P, Honoré T (1990) 2,3-Dihydroxy-6-nitro-7-sulfamoyl-benzo(F)quinoxaline: a neuroprotectant for cerebral ischemia. Science 247:571-574.

Shibuki K, Okada D (1991) Endogenous nitric oxide release required for long-term synaptic depression in the cerebellum. Nature 349:326328.

Siegelbaum SA, Kandel ER (1991) Learning-related synaptic plasticity: LTP and LTD. Curr Opin Neurobiol 1:113-120.

Stanton PK, Sejnowski TJ (1989) Associative long-term depression in the hippocampus induced by Hebbian covariance. Nature 339: 215-218.
Sugiura Y, Lee CL, Perl ER (1986) Central projections of identified unmyelinated $(\mathrm{C})$ afferent fibers innervating mammalian skin. Science 234:358-361

Sugiura Y, Terui N, Hosoya Y (1989) Difference in distribution of central terminals between visceral and somatic unmyelinated $(C)$ primary afferent fibers. J Neurophysiol 62:834-840.

Thompson SWN, King AE, Woolf CJ (1990) Activity-dependent changes in rat ventral horn neurons in vitro: summation of prolonged afferent evoked postsynaptic depolarizations produce a D-2-amino5-phosphonovaleric acid sensitive windup. Eur J Neurosci 2:638649.

Tsien RW, Malinow R (1990) Long-term potentiation: presynaptic enhancement following activation of postsynaptic $\mathrm{Ca}^{2+}$-dependent protein kinases. Cold Spring Harbor Symp Quant Biol 55:147-159.

Urbán L, Randić M (1984) Slow excitatory transmission in rat dorsal horn: possible mediation by peptides. Brain Res 290:336-341.

Watkins JC, Evans RH (1981) Excitatory amino acid transmitters. Annu Rev Pharmacol Toxicol 21:165-204.

Watkins JC, Krogsgaard-Larsen P, Honoré T (1990) Structure-activity relationships in the development of excitatory amino acid receptor agonists and competitive antagonists. Trends Pharmacol Sci 11:2533.

Wigström H, Gustafsson B (1985) Facilitation of hippocampal longlasting potentiation by GABA antagonists. Acta Physiol Scand 125: 159-172.

WoolfCJ (1983) Evidence for a central component of post-injury pain hypersensitivity. Nature 306:686-688.

Woulf CJ, Wall PD (1986) Relative effectiveness of C primary afferent fibers of different origins in evoking a prolonged facilitation of the flexor reflex in the rat. $J$ Neurosci 6:1433-1442.

Xie X, Berger TW, Barrionuevo G (1991) Long-term potentiation of NMDA receptor mediated synaptic transmission at the perforant pathgranule cell synapse in rabbit hippocampal slices. Third IBRO World Congr Neurosci Abstr, p 304.

Yoshimura M, Jessell TM (1989) Primary afferent-evoked synaptic responses and slow potential generation in rat substantia gelatinosa neurons in vitro. J Neurophysiol 62:96-108.

Yoshimura M, Jessell TM (1990) Amino acid-mediated EPSPs at primary afferent synapses with substantia gelatinosa neurones in the rat spinal cord. J Physiol (Lond) 430:315-335.

Yoshimura M, Nishi S (1993) Blind patch-clamp recordings from substantia gelatinosa neurons in adult rat spinal cord slice: pharmacological properties of synaptic currents. Neuroscience 53:519-526. 